\title{
The Marshall Plan as Strategic Analogy: Implications for Post-Conflict Reconstruction Planning
}

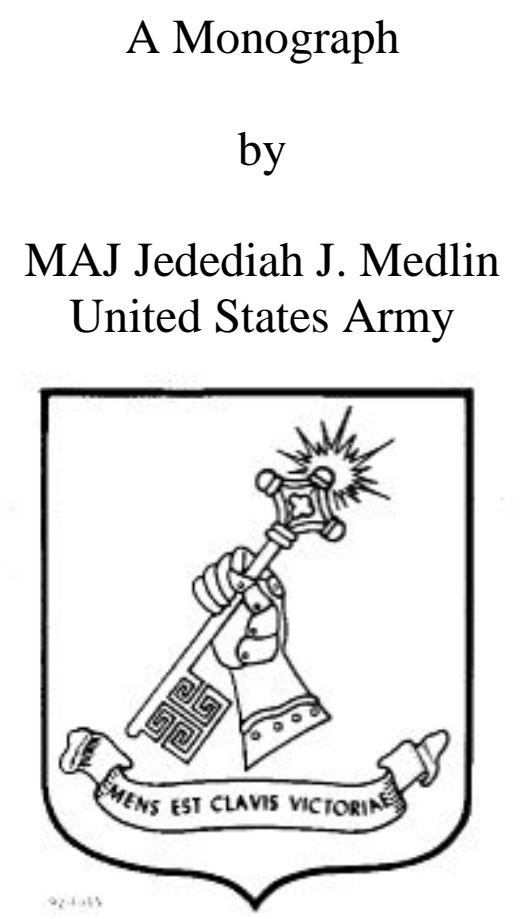

School of Advanced Military Studies United States Army Command and General Staff College

Fort Leavenworth, Kansas 


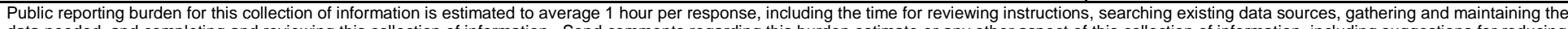

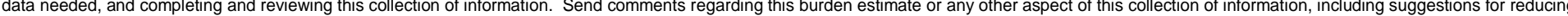

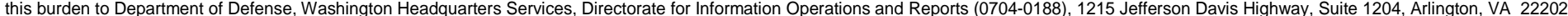

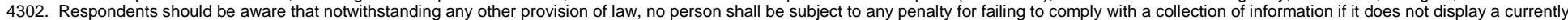
valid OMB control number. PLEASE DO NOT RETURN YOUR FORM TO THE ABOVE ADDRESS.

\begin{tabular}{l|l|l} 
1. REPORT DATE (DD-MM-YYYY) & 2. REPORT TYPE & 3. DATES COVERED (FrOm - To)
\end{tabular}

\begin{tabular}{l|l}
$12-04-2014$ & SAMS Monograph \\
\hline
\end{tabular}
JAN 2014 - DEC 2014

4. TITLE AND SUBTITLE

5a. CONTRACT NUMBER

The Marshall Plan as Strategic Analogy: Implications for Post-Conflict Reconstruction Planning

5b. GRANT NUMBER

5c. PROGRAM ELEMENT NUMBER

\section{AUTHOR(S)}

MAJ Jedediah Jamin Medlin

5d. PROJECT NUMBER

5e. TASK NUMBER

5f. WORK UNIT NUMBER

7. PERFORMING ORGANIZATION NAME(S) AND ADDRESS(ES)

School of Advanced Military Sciences (SAMS)

8. PERFORMING ORGANIZATION REPORT

201 Reynolds Avenue

Fort Leavenworth, KS 66027-2134 NUMBER

9. SPONSORING I MONITORING AGENCY NAME(S) AND ADDRESS(ES)

Command and General Staff College

10. SPONSOR/MONITOR'S ACRONYM(S) NUMBER(S)

731 McClellan Avenue

CGSC

Fort Leavenworth, KS 66027-1350

\section{DISTRIBUTION I AVAILABILITY STATEMENT}

Approved for Public Release; Distribution Unlimited

\section{SUPPLEMENTARY NOTES}

\section{ABSTRACT}

This monograph examines the use of the Marshall Plan as a strategic analogy for successful post-conflict success. It details what the Marshall Plan really was, what it accomplished, and how it did so in post-World War II Western Europe. In doing so, this research extracts five contextual variables that contributed to the Marshall Plan's success in Western Europe and applies them to recent post-conflict reconstruction efforts in Iraq and Afghanistan to determine the utility of the Marshall Plan as a strategic analogy for post-conflict success. This monograph concludes that the Marshall Plan analogy has been poorly applied creating troubling implications for phases IV (Stabilize) and V (Enable Civil Authority) operational planners. Planners must recognize the use of strategic analogy, understand its potential implications when used as a form of strategic guidance, see through analogy to seek the best understanding possible of the context they face, and develop a solution to future post-conflict operations that accounts for such context.

\section{SUBJECT TERMS}

Marshall Plan, Strategic Analogy, Post-Conflict Reconstruction, Phases IV and V, Western Europe, Iraq, Afganistan

\begin{tabular}{|c|c|c|c|c|c|}
\hline \multicolumn{3}{|c|}{ 16. SECURITY CLASSIFICATION OF: } & \multirow{2}{*}{$\begin{array}{l}17 . \\
\text { LIMITATION } \\
\qquad \text { UU }\end{array}$} & \multirow{2}{*}{$\begin{array}{l}18 . \\
\text { NUMBER }\end{array}$} & 19a. NAME OF RESPONSIBLE \\
\hline $\begin{array}{l}\text { a. REPORT } \\
\text { Unclassified }\end{array}$ & $\begin{array}{l}\text { b. ABSTRACT } \\
\text { Unclassified }\end{array}$ & $\begin{array}{l}\text { c. THIS PAGE } \\
\text { Unclassified }\end{array}$ & & & $\begin{array}{l}\text { 19b. TELEPHONE NUMBER } \\
\text { (include area code) } \\
913-758-3302\end{array}$ \\
\hline
\end{tabular}




\section{Monograph Approval Page}

Name of Candidate: MAJ Jedediah J. Medlin

Monograph Title: The Marshall Plan as Strategic Analogy: Implications for Post-Conflict Reconstruction Planning

Approved by:

Jeffrey J. Kubiak, PhD

, Monograph Director

Seminar Leader

Andrew Morgado, COL

, Director, School of Advanced Military Studies

Henry A. Arnold III, COL

Accepted this 4th day of December 2014 by:

Robert F. Baumann, PhD

, Director, Graduate Degree Programs

The opinions and conclusions expressed herein are those of the student author and do not necessarily represent the views of the U.S. Army Command and General Staff College or any other governmental agency. (References to this study should include the foregoing statement.) 


\begin{abstract}
The Marshall Plan as Strategic Analogy: Implications for Post-Conflict Reconstruction Planning, by MAJ Jedediah J. Medlin, 61 pages.

This monograph examines the use of the Marshall Plan as a strategic analogy for successful postconflict success. It details what the Marshall Plan really was, what it accomplished, and how it did so in post-World War II Western Europe. In doing so, this research extracts five contextual variables that contributed to the Marshall Plan's success in Western Europe and applies them to recent post-conflict reconstruction efforts in Iraq and Afghanistan to determine the utility of the Marshall Plan as a strategic analogy for post-conflict success. This monograph concludes that the Marshall Plan analogy has been poorly applied creating troubling implications for phases IV (Stabilize) and V (Enable Civil Authority) operational planners. Planners must recognize the use of strategic analogy, understand its potential implications when used as a form of strategic guidance, see through analogy to seek the best understanding possible of the context they face, and develop a solution to future post-conflict operations that accounts for such context.
\end{abstract}




\section{Contents}

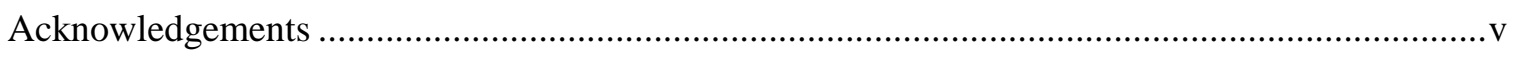

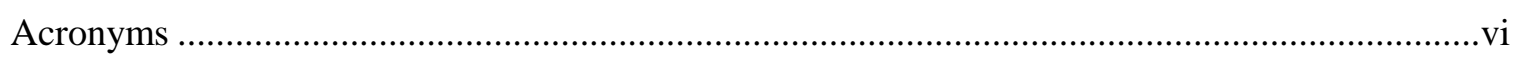

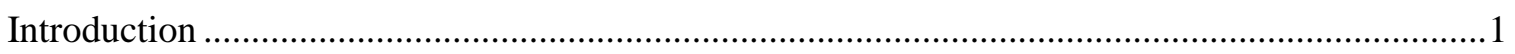

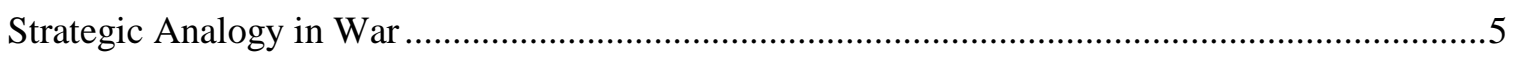

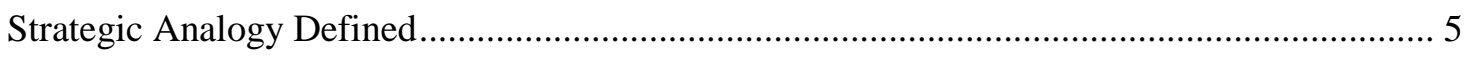

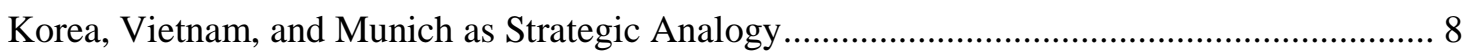

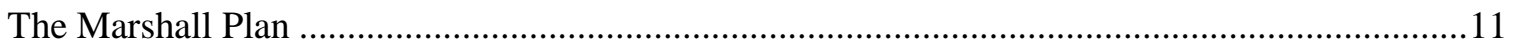

Implications of the Post-World War II Strategic Context................................................... 11

The Economic Cooperation Act of 1948: Setting the Conditions.......................................... 15

Implementation: By, With, and Through European Institutions .......................................... 16

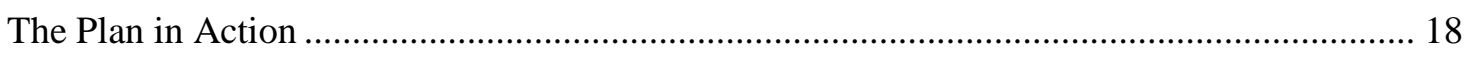

The Marshall Plan’s Effects and Implications .................................................................. 20

Contextual Variables of the Marshall Plan’s Success........................................................... 22

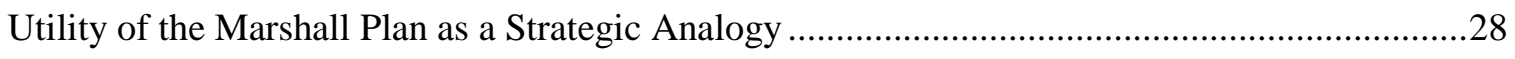

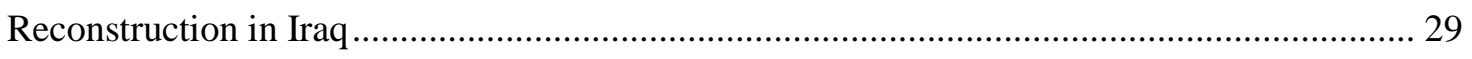

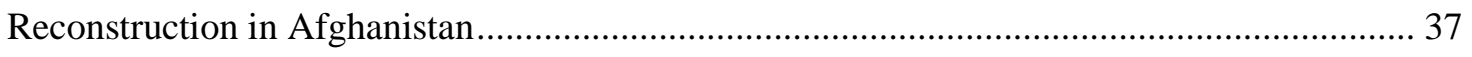

The Marshall Plan Analogy’s Relevance to Recent Reconstruction Efforts ........................... 43

Implications of the Marshall Plan Analogy’s Usage............................................................ 44

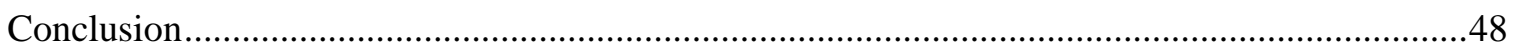

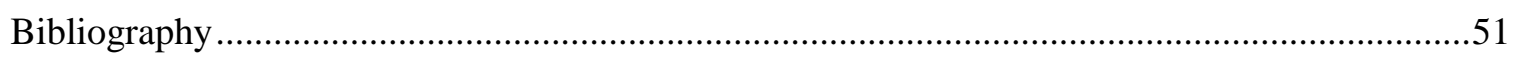




\section{Acknowledgments}

I would like to thank COL Robert K. Bertrand for his positive leadership and mentorship that made my attendance at SAMS and therefore this monograph possible. It was our beginnings, standing up the 80th Civil Affairs Battalion aligned with US Army Europe, that sparked my interest in the Marshall Plan. I appreciate my monograph director Dr. Jeffrey Kubiak’s support through this process and would like to especially thank him for introducing me to the topic of strategic analogy. Most of all, I want to thank Eun Jun, Marie-Noelle, and Ella. There were too many times over the last year when I was locked away reading and writing. I am thankful for Eun Jun's support and hope that one day Marie-Noelle and Ella will understand and appreciate why their father worked so hard. 


\section{Acronyms}

CEEC Committee of European Economic Cooperation

CPA Coalition Provisional Authority

ECA Economic Recovery Administration

OEEC Organization for European Economic Cooperation 


\section{Introduction}

To stabilize Europe in the aftermath of World War II, the United States implemented the Marshall Plan, officially known as the European Recovery Program, with the passage of the Economic Cooperation Act of 1948. ${ }^{1}$ Nearly sixty-five years later, the Marshall Plan's role in the successful post-World War II reconstruction and a resulting sustained European peace have made it nearly synonymous with successful post-conflict recovery. Appeals, both internationally and domestically, to bring back a Marshall Plan for recent post-war reconstruction efforts in Afghanistan and Iraq are characterized internationally by the Indian External Affairs Minister’s statement that “conceptually, there is a need for something like a 'Marshall Plan' for Afghanistan, involving all major stakeholders.”2 Domestically, in a 2002 graduation speech at the Virginia Military Institute, President George W. Bush referred to the Marshall Plan as “a beacon to light the path that we too must follow" and that "by helping to build an Afghanistan that is free from this evil and is a better place in which to live, we are working in the best traditions of George Marshall.”3 In September 2003, both international and domestic post-war reconstruction thoughts were focused on Iraq when President Bush remarked to the United Nations General Assembly that in Iraq, “the old regime built up armies and weapons, while allowing the nation's infrastructure to crumble, so we are rehabilitating power plants, water and sanitation facilities, bridges and airports. I proposed to Congress that the United States provide additional funding for

${ }^{1}$ Theodore A. Wilson, The Marshall Plan: An Atlantic Venture of 1947-1951 and How it Shaped Our World (New York: Foreign Policy Association, 1977), 37.

${ }^{2}$ Hindustan Times Correspondent, “India Backs Marshall Plan for Afghanistan,” Hindustan Times, December 5, 2011, accessed February 14, 2014, http://www.hindustantimes.com/world-news/india-backs-marshall-plan-for-afghanistan/article1778248.aspx.

${ }^{3}$ George W. Bush, “President George W. Bush’s speech at VMI on April 17, 2002, Cable News Network, accessed February 19, 2014, http://cgi.cnn.com/TRANSCRIPTS/0204/17/ se.02.html. 
our work in Iraq, the greatest financial commitment of its kind since the Marshall Plan.”4 In October 2003 and supporting President Bush’s Marshall-type proposal, Senator Alexander (RTN) stated that the US post-World War II reconstruction policy was “a complete success. That's why I believe we need a Marshall Plan for Iraq.”5

The international development community also picked up President Bush’s 2002 Marshall Plan analogy. In a 2003 hearing with the Senate Foreign Relations Committee, the executive vice president for Mercy Corps stated that “despite early pledges at the Tokyo donor conference in 2002, and an April 2002 declaration of a Marshall Plan for Afghanistan by President Bush, Afghanistan has only received a fraction of the $\$ 10.2$ billion the World Bank/United Nations Development Program assessment identified as necessary for the first five years.” In 2007, the Marshall Plan as an analogy for post-conflict success continued to appear in domestic political discourse. Senator Biden (D-DE) stated, “Afghan reconstruction is stuck in first gear. President Bush promised a Marshall Plan, but he’s delivered less development aid in the past five years than we spend on the war in Iraq every three weeks.” 6

The Marshall Plan has not only become an analogy for successful, large-scale, post-war reconstruction, but has grown well beyond its original context. It is applied as a panacea for, and road map to, the resolution of seemingly any large, complex, and comprehensive global or

${ }^{4}$ George W. Bush, "Statement by His Excellency Mr. George W. Bush, President of the United States of America Address to the United Nations General Assembly September 23, 2003," United Nations, accessed February 20, 1014, http://www.un.org/webcast/ga/58/statements/ usaeng030923.htm.

${ }^{5}$ Senator Lamar Alexander, “Alexander: A Marshall Plan is Needed for Iraq,” The Chattanoogan, October 3, 2003, accessed February 20, 2014, http://www.chattanoogan.com/ 2003/10/3/41700/Alexander-A-Marshall-Plan-Is-Needed.aspx.

${ }^{6}$ Senator Joseph R. Biden, Jr., "Opening Statement in the Senate Foreign Relations Committee Hearing on Afghanistan - Time for a New Strategy?” United States Senate Committee on Foreign Relations, March 8, 2007, accessed May 28, 2014, http://www.foreign. senate.gov/imo/media/doc/BidenStatement070308.pdf, 2. 
domestic problem that requires a governmental solution. For example, in a 2005 joint press release regarding Hurricane Katrina recovery, the Senate Majority Leader, Senator Harry Reid (D-NV), and Speaker of the House, Representative Nancy Pelosi (D-CA), stated that "it will take more than dollars to rebuild communities and that's why we have offered a Marshall Plan to help families get back on their feet, back into homes, and back on the job.”7 Also before becoming vice president in 1992, Al Gore called for a global Marshall Plan for global sustainable development issues. ${ }^{8}$

The Marshall Plan analogy persists into 2014. In the March 2014 edition of The American Legion: The Magazine for a Strong America, Joanne King Herring, a Houston political activist portrayed by Julia Roberts in Charlie Wilson's War, called for a Marshall Plan for Afghanistan. In the spirit of such a plan, her Marshall Plan charities organization constructed one village in Afghanistan based upon five lines of effort: clean water, food, health care, schools, and jobs with Afghans matching fifty percent of the financial requirements with local land or labor in an effort to build viable Afghan villages. Herring's goal was to put local Afghans back to work and alleviate poverty and, in doing so, undermine Taliban support. ${ }^{9}$ Further, the Iraq and Afghanistan Veterans of America even called for a Marshall-type plan to help veterans in response to the Department of Veterans Affairs scandal in June 2014. ${ }^{10}$

${ }^{7}$ Senator Harry Reid and Representative Nancy Pelosi, "Pelosi and Reid: America Needs Leadership in Recovery, Rebuilding, and Renewal,” Nancy Pelosi, September 15, 2005, accessed February 21, 2014, http://pelosi.house.gov/news/press-releases/pelosi-and-reid-america-needs-leadership-inrecovery-rebuilding-and-renewal.

${ }^{8} \mathrm{Al}$ Gore, Earth in the Balance: Ecology and the Human Spirit (Boston: Houghton Miffin, 1992).

${ }^{9}$ Jeff Stoffer, “A Marshall Plan for Afghanistan,” The American Legion: The Magazine for a Strong America 176, no. 3 (March 2014): 48-52.

${ }^{10}$ Richard Simon, “Veterans Group Pushes for a 'Marshall Plan' to Address VA Member Issues,” Los Angeles Times, June 2, 2014, accessed June 9, 2014, http://www.latimes.com/nation/ nationnow/la-na-nn-veterans-va-fixes-20140602-story.html?\{\{\$par\}\}. 
Among political and strategic leaders, and those that influence them both formally and informally, the Marshall Plan has become an analogy for successful post-conflict recovery and beyond. This research seeks to both investigate the Marshall Plan's usefulness as an analogy for understanding post-conflict reconstruction and examine potential implications of its use in recent reconstruction efforts. The widespread use of this strategic analogy by national leaders compels the operational artist to develop a thorough understanding of what the Marshall Plan really was, what it accomplished, and how it did so in the context of post-World War II Europe to identify and account for implications that may affect the operational planner's ability understand the problem at hand and to develop effective phases IV (Stabilize) and V (Enable Civil Authority) plans. ${ }^{11}$ It concludes that the Marshall Plan has been a poorly applied strategic analogy with troubling consequences for both operational planners and their unified action partners.

This research begins by investigating the use of analogy in war by strategic leaders. It conducts a unique examination of the Marshall Plan to assist in seeing through the analogy into what the Marshall Plan really was and what it did. This analysis will capture the aspects of the specific context of the Marshall Plan and its implementation that were most important to its perceived success. From this examination, it analyzes the applicability of such an analogy to the recent reconstruction efforts in Iraq and Afghanistan. Finally, this research provides analysis and conclusions regarding the utility of the analogy and implications for phases IV and V operational

${ }^{11}$ Joint Publication (JP) 5-0, Joint Operational Planning (Washington, DC: Government Printing Office, 2011), III-39 details notional operational plan phases. Phase 0 is Shaping, Phase I is Deter, Phase II is Seize Initiative, Phase III is Dominate, Phase IV is Stabilize, and Phase V is Enable Civil Authority. Within this construct, phases IV and V are post-conflict phases. 
planners and their unified action partners. ${ }^{12}$

\section{Strategic Analogy in War}

Strategic Analogy Defined

Joint doctrine states “[s]trategic guidance comes in many forms and provides purpose and focus for joint operational planning. Joint operation planners must know where to look for the guidance to ensure that plans are consistent with national priorities and are directed toward achieving national security objectives." ${ }^{13}$ In situations not addressed in traditional strategic documents such as the National Security Strategy, National Defense Strategy, or National Military Strategy, such guidance may be found in, or inferred through, the statements of strategic leaders using analogy. ${ }^{14}$ Strategic analogy is a method by which leaders may use history to facilitate contemporary decision-making in difficult, uncertain security environments. It is a means whereby policy makers compare a particular strategic, national security issue to a perceived historical event that is similar in nature. In doing so, policy makers invoke historical experiences to help understand, describe, and prescribe action in the face of complex problems. The use of analogy by strategic policy makers is neither a new phenomenon nor is it isolated to the reconstruction of post-World War II Europe.

${ }^{12}$ Army Doctrine Reference Publication (ADRP) 3-0, Unified Land Operations (Washington, DC: Government Printing Office, 2012), 1-3. ADRP 3-0 defines unified action partners as "those military forces, governmental and nongovernmental organizations, and elements of the private sector with whom Army forces plan, coordinate, synchronize, and integrate during the conduct of operations. Unified action partners include joint forces and components, multinational forces, and U.S. government agencies and departments.”

13 JP 5-0, II-1.

${ }^{14}$ Ibid., II-1 and II-2. According to JP 5-0, traditional strategic guidance is given in these strategic documents; however, "[a]t times, JFCs may not receive clear strategic guidance and will need to engage the strategic leadership in order to assist with plan development and the proposal of a feasible strategic end state.” Such engagement whether face to face, other informal

correspondence, or through speeches such as President Bush's graduation speech at VMI in 2002 is where the influence of a strategic leader using analogy may be of influence. 
According to Yuen Foong Khong, a professor of international relations at Oxford University, analogies help strategic leaders identify and understand the problem at hand by comparing a contemporary problem to a similar historical situation. In doing so, primacy is given to the similarities rather than the differences between the two situations. In his book Analogies at War, Khong continues to argue that once this comparison is made, the use of the established analogy provides a basis from which to understand the potential political or strategic-level implications of the contemporary situation and, based upon the similar historical example, to begin to prescribe policy solutions to the current problem at hand. ${ }^{15}$ Once the strategic analogy is established and policy prescriptions are formed into directives for action, Khong argues that the analogy is used to predict the potential effectiveness of a chosen policy approach, determine the course of action's strength based upon morality, and to foresee any potential risks involved with the chosen proposed solution. ${ }^{16}$ Thus, Khong argues that analogies frame one’s understanding of a problem, dictate potential policy courses of action while excluding others, and predict both the likelihood of success and the risks of chosen approaches within a moral framework.

According to Jeffrey Record, a professor of strategy and international security at the US Air Force's Air War College, there are both positives and negatives of using analogy in strategic decision-making. Analogies based upon past experiences can be effective at the general level, however they do not capture the detail required for effective judgment. ${ }^{17}$ In The Reluctant Superpower: United States Policy in Bosnia, 1991-1995, Wayne Bert, a former international politics and Asian studies professor at George Washington University, states, “[b]ut reasoning by

${ }^{15}$ Yuen Foong Khong, Analogies at War: Korea Munich, Dien Bien Phu, and the Vietnam Decisions of 1965 (Princeton, NJ: Princeton University Press, 1992), 20-21.

${ }^{16}$ Ibid., 21.

${ }^{17}$ Jeffrey Record, Making War, Thinking History: Munich, Vietnam, and Presidential Uses of Force from Korea to Kosovo (Annapolis, MD: Naval Institute Press, 2002), 156. 
analogy is also inadequate. Since a given event is almost never the same as a past event, and the environment in which events take place is changed and conditions are different, it is risky to assume that a past event or outcome can be used as an effective model for a present one.” ${ }^{18}$ Along these lines, John Lewis Gaddis, a Cold War expert and professor of military and naval history at Yale University, further suggests that "science, history, and art have something in common: they all depend on metaphor, on the recognition of patterns, on the realization that something is 'like' something else.” ${ }^{19}$ Although understanding history is an advantage, Gaddis argues in The Landscape of History: How Historians Map the Past that one must be cautious in using history to predict the future. He further argues that we can only represent the past since we cannot go back in time and actually experience historical events within their appropriate contexts. Therefore, the contexts of particular events are important in using strategic analogy in the comparison of contemporary and historical problems. Further, Richard E. Neustadt and Ernest R. May, government and history professors at Harvard University, argue that “[s]eeing the past can help one envision alternate futures. But, we concede that analysis can also be an enemy of vision.”20 Therefore, obtaining the best possible understanding of historical events within their appropriate contexts is fundamental in their effective comparisons to contemporary problems using strategic analogy.

${ }^{18}$ Wayne Bert, The Reluctant Superpower: United States Policy in Bosnia, 1991-1995 (New York: St. Martin’s Press, 1997), 111, quoted in Record, 156.

${ }^{19}$ John Lewis Gaddis, The Landscape of History: How Historians Map the Past (New York: Oxford University Press, 2002), 2.

${ }^{20}$ Richard E. Neustadt and Ernest R. May, Thinking in Time: The use of History for Decision-Makers (New York: The Free Press, 1986), xv. 
Korea, Vietnam, and Munich as Strategic Analogy

American strategic leaders have routinely called upon memories of Munich in 1938, and the US involvement in the Korean and Vietnam Wars as strategic analogies for late twentieth century crises. These examples, along with the potential effects of strategic analogy revealed in the previous section, depict potential consequences of the inappropriate use of the Marshall Plan analogy. Khong argues that the analogy of the Korean War led President Johnson both to US involvement in Vietnam and his administration's selection of a particular policy in the conflict by framing the administration's view of the problem and evaluating the political implications of the issue. The analogy guided actual policy choices and estimated their chances of success, and evaluating both morality and risks involved with these policy prescriptions. Khong states that "the Korean analogy introduced choice propensities into the administration's decision-making: it predisposed those who took it seriously toward certain policy outcomes and turned them away from others. In doing so, it played an important role in influencing decision outcome." ${ }^{21}$ In fact, William Bundy, the Assistant Secretary of State for Far Eastern Affairs, compared the success of the Korean War in preserving an independent South Korea with the problem in Vietnam during a January 1965 speech at the Missouri Chamber of Commerce. ${ }^{22}$ Khong argues that not only did the Johnson administration compare the type of conflict in Korea to the emerging problem in Vietnam, but by using the analogy, also painted a high-stakes environment where something must be done. Moreover, if limited military involvement was the solution in Korea, it must also be the policy of choice in Vietnam. Further, according to Khong, if the situation in Vietnam in 1965 was like the situation in Korea in 1950, then not only should the Johnson administration undertake a
${ }^{21}$ Khong, 97.
${ }^{22}$ Ibid., 99. 
similar military policy, they are morally obliged to do so. ${ }^{23}$ Gideon Rose, the editor of Foreign Affairs and former National Security Council staff member concluded "[t]he only problem was that the two wars differed in such a crucial respect that the analogy was worthless.” ${ }^{24}$ The situation in Vietnam may have seemed like the situation in Korea and although perhaps similar, they were in fact distinct problems with differing contexts that needed to be analyzed on their own.

Khong also argues that the Munich analogy, referring to the appeasement of Adolf Hitler in 1938 at the Munich Conference, affected policy makers and influenced their decisions regarding US involvement in Vietnam. The Munich analogy results from the agreement among Neville Chamberlain, Edouard Daladier, Benito Mussolini, and Adolf Hitler to allow Nazi Germany to annex the Sudeten portion of Czechoslovakia in 1938 in exchange for peace in Europe. However, six months later Nazi Germany annexed the remainder of Czechoslovakia and later invaded Poland in September 1939 beginning World War II. ${ }^{25}$ Khong suggests that the Johnson administration learned and applied a policy based on an "aggression unchecked is aggression unleashed" analogy. ${ }^{26}$ The result of this analogy was the belief in a domino theory in Asia, similar to the continued aggression of Nazi Germany after the Munich Conference. In the end, the situation in Vietnam was not like Munich. South Vietnam fell and the threat of a domino effect spreading communism unchecked throughout Asia never transpired. As a result, US intervention in Vietnam may not have been the best course of action based upon the lesson from Munich. Jeffrey Record argues that the enduring result of the Munich analogy is a policy

${ }^{23}$ Khong, 101.

${ }^{24}$ Gideon Rose, How Wars End: Why We Always Fight the Last Battle (New York: Simon and Schuster, 2010), 179.

${ }^{25}$ Khong, 175.

${ }^{26}$ Ibid. 
prescription dictating the use of force which is exemplified by his characterization that small threats become bigger ones unless action is taken because "if you don’t stop Hitler in Czechoslovakia, he'll go on for Poland and the rest of Europe” and “[i]f you let stand Saddam's aggression against Kuwait, the next thing he'll do is grab Saudi Arabia.”27 The implications of the Munich analogy on policy makers dictate intervention when such perceived threats may remain small, never developing into the larger global threats.

Khong further argues that a Vietnam analogy has affected post-Cold War decisionmaking by determining when to use force and how to do so. ${ }^{28}$ According to Khong, the comparison of the Balkans to Vietnam after the dissolution of Yugoslavia resulted in the limited approach and lack of large forces on the ground. Fears of another Vietnam in the Balkans are evident in Robert McNamara's statement:

the odds of a long-term tragedy will be far greater if we don't apply the lessons the Vietnam conflict taught us. In fact, my greatest concern is that we and our adversaries may have already made mistakes that might have been avoided had we learned from experience. Studying the lessons of the Vietnam War may allow us to end this war earlier, ignoring them may result in catastrophe. ${ }^{29}$

McNamara reveals how analogy affected the Balkans.

Jeffrey Record argues that the Vietnam analogy warns strategic leaders of the danger of becoming involved in potential civil wars abroad and that there are constraints on what the use of military force can achieve. Gideon Rose states the memory of Vietnam directly affected the Gulf War in 1991; it "translated into skepticism about making the invasion of Kuwait a casus belli, reluctance to move from sanctions to war, insistence on overwhelming force to execute the
${ }^{27}$ Record, 6.
${ }^{28}$ Khong, 153.
${ }^{29}$ Robert McNamara, “Misreading the Enemy,” New York Times, April 21, 1999, quoted in Record, 156. 
mission given, and determination to limit the war's objectives and return home quickly.” 30 Record further argues that such an analogy is dangerous because it results in the assumption that policy makers can always enter wars of choice against opponents that can be quickly defeated. ${ }^{31}$ Therefore, the use of the lessons of Vietnam in deciding upon the use of military force has the potential to promulgate the assumption that the resulting conflict will not be like Vietnam.

Strategic analogy as a tool to help understand and simplify complex problems is not limited to the use and establishment of the Marshall Plan as the model for effective post-conflict reconstruction and phases IV (Stabilize) and V (Enable Civil Authority) planning. The historical use of Korea, Munich, and Vietnam as strategic analogy and the resulting influences on decision makers display the limitations and potential negative implications of the use of strategic analogy by strategic leaders to describe current, complex problems that may require the use of military forces. Similar implications may result from the use of the Marshall Plan as a strategic analogy. Having defined and provided examples of the use and effects of strategic analogy, this research will proceed by examining the Marshall Plan to subsequently determine the appropriateness of its use as an analogy for successful phases IV and V operations in Iraq and Afghanistan.

\section{The Marshall Plan}

Implications of the Post-World War II Strategic Context

An understanding of the Marshall Plan's strategic context is important in determining its applicability as a strategic analogy for successful post-conflict operations. George Kennan’s The Sources of Soviet Conduct offers an analysis of the Cold War where post-World War II tensions between the United States and Soviet Union formed a new bipolar security environment that shaped the Marshall Plan’s strategic context. Kennan argued for a containment strategy that
${ }^{30}$ Rose, 220.
${ }^{31}$ Record, 164-165. 
aimed to prevent Soviet expansion. This strategy was codified by both the Truman Doctrine and Marshall Plan, military and economic strategies that Cold War historian Walter Lafeber characterized as "two halves of the same walnut." ${ }^{32}$ In an October 1948 conversation with the Argentine foreign minister, and in reference to US economic support to Europe, Secretary of State George C. Marshall revealed the Marshall Plan’s role in foreign policy by stating, “[w]e had to build up the European situation first and thus prevent the spread of communism and the complete disintegration of Europe.” ${ }^{33}$ Thus, the Marshall Plan was more than a post-conflict recovery plan; it was also a strategic Cold War foreign policy instrument aimed to check Soviet expansion and power into Western Europe.

According to David M. Edelstein, a member of Georgetown University’s Security Studies Program and Center for Peace and Security Studies, this strategic context facilitated the Marshall Plan’s implementation. Western states, including the United States, United Kingdom, and France, were welcomed and readily accepted in West Germany, Western Austria, and Italy in particular because these nations perceived the Soviet and East German communists as a common external threat. ${ }^{34}$ Edelstein further states that the initial existence of a common external threat among an occupied population is directly related to the success of the resulting post-conflict rehabilitation. Without such a commonly perceived external threat, the occupying power must use coercion rather than cooperation to achieve its post-conflict objectives that limits the ability to incorporate the occupied nation into recovery goals and programs. ${ }^{35}$ The favorable threat

\footnotetext{
${ }^{32}$ X, “The Sources of Soviet Conduct,” Foreign Affairs 25, no. 4 (July 1947), 566.

${ }^{33}$ Robert L. Beisner, Edward M. Coffman, George C. Herring, and Edwin A. Thompson, eds., The Papers of George Catlett Marshall, vol. 6 (Baltimore: John C. Hopkins University Press, 2013), 570.

${ }^{34}$ David M. Edelstein, Occupational Hazards: Success and Failure in Military Occupation (Ithaca, NY: Cornell University Press, 2008), 183-184.

${ }^{35}$ Edelstein, 14.
} 
environment within Western Europe shaped by the Cold War's external Soviet threat was fundamental to its successful post-war recovery because the Marshall Plan faced less resistance and was able to incorporate a cooperative, joint strategy with recovering western European states. In 2002 Richard Haass, the State Department's director for policy planning prior to the war in Iraq, supported Edelstein by stating that “[e]very past reconstruction effort was built upon a bedrock of basic security. Without order and security at the local level, all else is jeopardized: the patterns of everyday life and commerce will not resume, refugees will not return home, private investment will remain scarce, and NGOs and international organizations will not operate.”36 Such a permissive, low threat post-conflict environment that results from security provides a positive feedback cycle for post-conflict recovery where the favorable threat environment allows an occupying power to implement a cooperative reconstruction strategy. This, in turn, leads the population to perceive the post-conflict forces or programs as a lesser and decreasing threat to its own factional or national interests. ${ }^{37}$

Even with a strategic context that facilitated a favorable security environment for postconflict reconstruction, the situation in Western Europe was grim two years after the war. Since the German surrender, military occupation forces had focused on economic and political recovery, food security, education, commodities, housing displaced persons, and electoral

${ }^{36}$ Richard N. Haass, Information Memorandum to the Secretary of State, "Reconstruction in Iraq-Lessons of the Past," September 26, 2002, declassified and released in full by the US Department of State, September 26, 2012.

${ }^{37}$ Edelstein, 55. 
preparation. ${ }^{38}$ However, the situation remained dire. By 1947, the United States became concerned about the post-conflict recovery in the face of lagging economic and social progress. ${ }^{39}$

At this point, the overarching post-conflict impediments to long-term post-conflict stability were economic in nature. The war's derailment of European economies and its destruction of economic infrastructure created more than poverty. It also left a situation where the means to remedy the problem were absent without external assistance. Markets had essentially failed in post-war Germany and a harsh 1946-47 winter further hampered recovery. Compared with economic output in 1938, post-war western European agriculture production measured only eighty-three percent, industrial outputs were at eight-eight percent, and imports were at fifty-nine percent of their pre-war capacities. ${ }^{40}$ Further, post-war Europe lacked the capital to fund imports that precluded healthy trade and the ability to sustain an economy.

Secretary of State George C. Marshall described the dire post-conflict situation in Europe, its causes, and implications in a June 5, 1947 speech to Harvard alumni in Cambridge, Massachusetts and established the basis for what would later become known as the Marshall Plan. In this speech, Marshall described the inauspicious state of the post-war European economy and its potential implications on a free, stable, and peaceful future on the continent. Marshall stated that the post-war "world situation is very serious . . . it has become obvious during recent months that the visible destruction was probably less severe than the entire dislocation of the European economy." ${ }^{41}$ Industry had been switched to wartime production and the war destroyed much of

${ }^{38}$ Christopher Knowles, “Germany 1945-1949: A Case Study in Post Conflict Reconstruction,” History and Policy, January 2014, accessed May 6, 2014, http://www.historyand policy.org/papers/policy-paper-154.html.

${ }^{39}$ Michael J. Hogan, The Marshall Plan: America, Britain, and the Reconstruction of Europe, 1947-1951 (New York: Cambridge University Press, 1987), 29.

${ }^{40}$ Ibid., 30.

${ }^{41}$ Beisner et al., 147. 
the machinery and equipment needed to revert to a peacetime economy. Further, the war and its economic implications disrupted the entire division of labor necessary for an efficient free market economy. As a result, Europe relied on agricultural imports to feed itself, but lacked the capital to fund both the industrial and agricultural imports to provide a long-term remedy to this underlying economic issue of post-conflict recovery, resulting in a balance of payments crisis. ${ }^{42}$

In response to this crisis, Marshall called for a joint program to get Europe back on its feet that required not just American, but also European involvement and self-investment. Marshall said:

[i]t would be neither fitting nor efficacious for our Government to undertake to draw up unilaterally a program designed to place Europe on its feet economically. This is the business of the Europeans. The initiative, I think, must come from Europe. The role of this country should consist of friendly aid. In the drafting of a European program and of later support of such a program so far as it may be practical [possible] for us to do so. The program should be a joint one, agreed to by a number, if not all European nations. ${ }^{43}$

Key aspects of Marshall's concept were framed around a threat environment that facilitated a cooperative strategy with both European buy-in and initiative and European self-investment in an effort to assist a post-war Europe help themselves and take ownership of their own reconstruction.

The Economic Cooperation Act of 1948: Setting the Conditions

Marshall’s June 1947 speech to Harvard alumni at Cambridge informed the spirit of the Economic Cooperation Act of 1948 that became popularly known as the Marshall Plan. The Economic Cooperation Act stated, "the Congress finds that the existing situation in Europe endangers the establishment of a lasting peace, the general welfare and national interest of the

\footnotetext{
${ }^{42}$ Beisner et al.,147-148.

43 Ibid., 149.
} 
United States, and the attainment of the objectives of the United Nations." ${ }^{44}$ Further, the act identified the underlying cause and way ahead to alleviate the situation in post-war Europe. According to the Economic Cooperation Act of 1948, the path towards democracy, sustained peace, and stability rested not on the tactical actions or stability tasks of an army of occupation, but in a macroeconomic approach to post-conflict recovery. It outlined the resulting Marshall Plan's broad actions by stating the following:

[t]he restoration or maintenance in European countries of principles of individual liberty, free institutions, and genuine independence rests largely upon the establishment of sound economic conditions, stable international economic relationships, and the achievement by the countries of Europe of a healthy economy independent of extraordinary outside assistance. The accomplishment of these objectives calls for a plan of European recovery, open to all such nations which cooperate in such plan, based upon a strong production effort, the expansion of foreign trade, the creation and maintenance of internal financial stability, and the development of economic cooperation, including all possible steps to establish and maintain equitable rates of exchange and to bring about the progressive elimination of trade barriers. ${ }^{45}$

By design, the Marshall Plan was neither a tactical phase IV or V reconstruction action nor an operational level plan that primarily focused directly at the people. Rather, it was a strategic level, macro-economic recovery plan that was engrained in US foreign policy and provided a top-down, cooperative approach within the post-World War II strategic environment.

Implementation: By, With, and Through European Institutions

The Marshal Plan’s strategic context, its approach outlined in the Economic Recovery Act of 1948, and how the Marshall Plan worked by, with, and through strong European institutions to achieve its end state provide important insights for evaluating its applicability as a strategic analogy for post-conflict success. Based on Marshall’s June 1947 speech to the Harvard alumni, Europeans gathered in Paris on July 12, 1947 for what would become known as the Paris 1948.

${ }^{44}$ Economic Cooperation Act of 1948, Public Law 472, 80th Cong., 2d sess. April 3, ${ }^{45}$ Ibid. 
Conference to consider how to respond to a future Marshall Plan. ${ }^{46}$ Representatives from sixteen countries attended: Austria, Belgium, Denmark, France, Greece, Iceland, Ireland, Italy, Luxembourg, the Netherlands, Norway, Portugal, Sweden, Switzerland, Turkey, and the United Kingdom. ${ }^{47}$ These sixteen European foreign ministers developed the Committee of European Economic Cooperation (CEEC) during the Paris Conference. ${ }^{48}$ The CEEC, as a temporary organization, took ownership of European recovery and provided a basis for further European buy-in and coordination of future Marshall Plan economic assistance.

The Marshall Plan's cooperative approach allowed the CEEC to identify the four areas most in need of economic recovery and established committees for each: food and agriculture, iron and steel, fuel and power, and transportation. ${ }^{49}$ As a European institution, the CEEC released a draft report on September 22, 1947 that detailed a four-pronged plan for European recovery: increase agricultural and industrial production, control inflation and monetary stability, close the import and export gap, and to create a more permanent institution. ${ }^{50}$ Regionally, Europeans identified their own priorities for the European recovery. The assembly at Paris, the establishment of the CEEC as an intra-European institution that focused on post-war recovery, and its organization and actions provided an initial basis for future Marshall Plan funding to be implemented cooperatively by, with, and through that served as an example for future institutions to facilitate trade. It also laid the foundation among Europeans and their institutions for the Marshall Plan to follow.

${ }^{46}$ Greg Behrman, The Most Noble Adventure: The Marshall Plan and the Time When America Helped Save Europe (New York: Free Press, 2007), 96.

${ }^{47}$ Wilson, 25.

${ }^{48}$ Ibid., 26.

${ }^{49}$ Behrman, 97.

${ }^{50}$ Wilson, 31. 
The Plan in Action

The Economic Cooperation Act of 1948 also established the Economic Cooperation Administration (ECA) to serve as the conduit for funneling Marshall Plan funds to Western Europe. European nations receiving financial aid from the ECA had to match the US dollar amount provided with their own currency equivalent and deposit this in a specific fund as the basis for investment in their own recovery projects. ${ }^{51}$ The financial effort was shared among recipients and the ECA. Ambassador Constance Morella, a former US representative to the Organization for Economic Cooperation and Development, described the importance of this mutual US-European effort by stating:

[a]mong the secrets for success of the Marshall Plan, as the Economic Recovery Act came to be known, was the spirit of cooperation evidenced in its execution. The program was truly a joint European-American venture, one in which American resources were complemented with local resources and all the participants worked cooperatively toward the common goals of freedom and prosperity. ${ }^{52}$

Such a cooperative system ensured further European ownership and buy-in of the postconflict recovery through the self-investment of participating nations. By July 1948, approximately $\$ 738$ million in grants to CEEC countries were available. ${ }^{53}$ However, the specifics of using such funding to support local economic recovery at the state level were not dictated by the ECA. The Marshall Plan required European, not only American, initiative, planning, and solutions.

${ }^{51}$ Wilson, 31.

${ }^{52}$ Constance A. Morella, "Marshall Plan 60th Anniversary Symposium: Introductory Remarks," in The Marshall Plan: Lessons Learned for the 21st Century, edited by Eliot Sorel and Pier Carlo Padoan (Paris: OECD Publications, 2008), 6.

${ }^{53}$ Wilson, 41. 
The plan mandated the foundation of a European intergovernmental institution that would facilitate economic integration among western European states. ${ }^{54}$ Out of this requirement, the Organization for European Economic Cooperation (OEEC), the predecessor of today's Organization for Economic Cooperation and Development, emerged from the CEEC. The OEEC included all sixteen members of the CEEC and West Germany; it provided a European solution to the distribution of ECA funding by year. ${ }^{55}$ In addition, this newly formed inter-European economic institution fostered the following principles:

promote co-operation between participating countries and their national production programmes for the reconstruction of Europe, develop intra-European trade by reducing tariffs and other barriers to the expansion of trade, study the feasibility of creating a customs union or free trade area, study multi-lateralisation of payments, and achieve conditions for better utilization of labour. ${ }^{56}$

The Marshall Plan was designed to work through this institution in a multilateral approach towards western European economic integration by integrating markets, assisting participating members, and reducing economic protectionism. It was never intended to deal with one state alone; rather, it was a regional approach. ${ }^{57}$

By the summer of 1949, slightly more than a year after the passage of the Economic Cooperation Act of 1948 and the establishment of the ECA, nearly six billion dollars had gone to OEEC members. Although OEEC member countries took the lead, execution required at least

\footnotetext{
${ }^{54}$ Morella, 6.

${ }^{55}$ Wilson, 42.

${ }^{56}$ OECD, “Organization for European Economic Cooperation,” last modified May 3, 2013, accessed May 6, 2014, http://www.oecd.org/general/organisationforeuropeaneconomicco-

${ }^{57}$ Barry Machado, “A Useable Marshall Plan,” in The Marshall Plan: Lessons Learned
} operation.htm. for the 21st Century, 59. 
silent US consent. ${ }^{58}$ Most of the money assisted the balance of payments issue in Europe and funded US commodity imports. By the second quarter of the 1949 calendar year, agricultural production had increased substantially and industrial production markedly surpassed indices immediately preceding the war. ${ }^{59}$ By 1949 , it became apparent that the influx of financial assistance coupled with European efforts had sparked the desperately needed economic recovery. ${ }^{60}$ Theodore Wilson, professor of history at the University of Kansas, noted, “these achievements, amounting to an economic miracle, were made possible by an infusion of US aid that amounted to no more than four percent of Western Europe’s GNP for the same period.”61 In addition to successes, Chinese intervention in the Korean War in late 1950 and the resulting emphasis on defense spending, both domestically and within the North Atlantic Treaty Organization, brought the Marshall Plan funding to an end. ${ }^{62}$ The plan officially ended on December 30, $1951 .{ }^{63}$

The Marshall Plan’s Effects and Implications

By the time the Marshall Plan ended, the ECA had provided nearly thirteen billion dollars, more than $\$ 100$ billion in 2008 US dollars, to OEEC states ${ }^{64}$ For a comparatively low price the US investment assisted western European gross domestic capital growth by 30.1 percent

${ }^{58}$ Imanuel Wexler, The Marshall Plan Revisited: The European Recovery Program in Economic Perspective. (Westport, CT: Greenwood Press, 1983), 18.

${ }^{59}$ Wilson, 42.

${ }^{60}$ Ibid., 44.

${ }^{61}$ Ibid., 43.

${ }^{62}$ Hogan, 380.

${ }^{63}$ Wexler, 249.

${ }^{64}$ Morella, 5. 
between 1948 and $1951 .{ }^{65}$ Additionally, the Marshall Plan had another important regional implication; it facilitated western European integration. The economic success from the Marshall Plan trickled into European domestic and international political and social institutions. Historian Charles L. Mee, Jr. argues that the Marshall Plan hampered the rise of the Communist party in Western Europe, strengthened liberal political institutions, and drew Western Europe closer together in the aftermath of the war. ${ }^{66}$ The inter-European cooperation among participating western European states, first through the CEEC and then through the OEEC, not only provided strong institutions for post-conflict recovery, but laid the foundations for future western European integration with plans for a western European military alliance that was institutionalized in the North Atlantic Treaty Organization. ${ }^{67}$

In addition, recipient countries within the OEEC had the strong, western economic and political institutions necessary to facilitate the effective domestic implementation of a macroeconomic, Keynesian fiscal stimulus. These institutions provided monetary stabilization and controlled wages throughout the stimulus that helped to keep inflation in check and maximized funds available for infrastructure investment. ${ }^{68}$ Further, strong institutions in a more integrated Western Europe reduced tariffs and trade barriers, resulting in a gross consumer gain and net national gain that maximized economic growth. ${ }^{69}$ The United States could not have been this successful in the long-term stabilization of post-conflict Europe with a unilateral approach or without the benefit of pre-existing conditions to facilitate the proper planning and use of Marshall

${ }^{65}$ Wexler, 251.

${ }^{66}$ Charles L. Mee, Jr. The Marshall Plan: The Launching of Pax Americana (New York: Simon and Schuster, 1984), 262.

${ }^{67}$ Ibid., 260.

${ }^{68}$ Ibid., 262.

${ }^{69}$ Ibid. 
Plan funding. None of this would have been possible without viable, western domestic and European institutions cooperating with the ECA.

Contextual Variables of the Marshall Plan’s Success

Based on an analysis of the Marshall Plan’s strategic environment, its concept, and implementation, it is possible to identify critical contextual variables that were central to enabling its role in the successful reconstruction of Western Europe after World War II. Establishing these variables allows for the further analysis of the Marshall Plan’s applicability as an analogy for successful post-conflict operations in recent reconstruction operations in Iraq and Afghanistan. The Marshall Plan's central role in the successful reconstruction of post-World War II Western Europe was largely shaped by these five contextual variables: (1) high strategic stakes; (2) presence of a commonly perceived external threat; (3) the internal security environment; (4) the plan's cooperative approach; and (5) the plan's implementation through strong European (western) institutions. While it is obvious that these five variables are deeply interrelated and inseparably linked, they are still analytically useful for evaluating the impact of using the Marshall Plan as a strategic analogy for other reconstruction efforts.

\section{Strategic Stakes}

Strategic stakes refer to the implications of strategic risk at the national level. This is not the risk of failing to meet strategic objectives, but the implications associated with the inability to do so. From the perspective of both the beneficiary and benefactor, strategic stakes provide a mechanism that affects support and political will for reconstruction. In addition, strategic stakes establish the consequences of failure that, when high, necessitate a prompt, effective response. When low, a less timely response with more tolerance for error is more likely accepted.

Strategically, the threat communism posed to the American and western ways of life created a high stakes environment in post-World War II Europe that contributed to the Marshall 
Plan's success in the face of the emerging Cold War. In 1947, George Kennan as Mr. X argued that the Soviet Union was a rival in the international arena and should be treated as such because of Soviet "ideology and circumstance."70 According to Kennan, the United States could not reach any sort of settlement or agreement with the Soviets because of the influence of their BolshevistMarxist ideology that believed in both the inherent threat of capitalist societies and an imperialist nature of capitalism that ultimately results in conflict. ${ }^{71}$ Further, the circumstances of the Russian Revolution of 1917 strengthened such beliefs. The need to eradicate the internal capitalist threat was necessary in order to consolidate the communist regime after the revolution. Soviet insecurity resulting from this regime consolidation process led to "a skepticism as to the possibilities of permanent and peaceful coexistence of rival forces." ${ }^{72}$ According to Kennan, this ideology and insecurity was reflected in Soviet foreign policy as well because it "taught them that the outside world was hostile and that it was their duty eventually to overthrow the political forces beyond their borders.”73 Therefore, failing to check Soviet expansion into Western Europe and not unifying Western Europe economically with a Marshall Plan that was nested in US foreign policy posed a perceived existential threat to capitalist society and democracy as a whole. These high stakes for both the United States and its western European allies rallied immense popular and congressional support for the Marshall Plan and provided a sense of urgency to address conditions within Western Europe that left without a prompt, focused response could risk the democratic stability of western European governments. ${ }^{74}$
${ }^{70} \mathrm{X}, 566$.
${ }^{71}$ Ibid.
72 Ibid., 568.
${ }^{73}$ Ibid., 569.
${ }^{74}$ Wilson, 32. 


\section{External Threat Perception}

External threat perception is the realized threat that another country poses to the reconstruction beneficiary as seen by its society. When such an external threat exists and is perceived as greater than the threat of the reconstruction efforts by foreign forces, this provides a mechanism that unites the post-conflict population in support of reconstruction efforts and the associated security forces. ${ }^{75}$ Further, such a perceived external threat can serve as a unifying factor among the various political factions within the society. Although the strategic environment may include an external threat, its perception by the benefactor and its potentially unifying mechanism, rather than its mere presence, warrants analysis.

The commonly perceived external threat that the Soviet Union provided within this high stakes security environment facilitated the Marshall Plan's success. Threatened by the Soviet Union on the continent, western European recipient nations viewed this communist threat as much more threatening than any US influence in the region or potential social-political internal fragmentations. Refugees from Soviet occupied areas arrived in Western Europe with depictions of Soviet maltreatment, causing western Europeans to see occupation forces and their programs as protection from this Soviet threat. In addition to pre-existing nationalism in Western Europe, the perception of this external threat provided cohesion despite internal political divides. ${ }^{76}$

\section{Security Environment}

The internal security environment refers to the level of violence between factions within a society and against post-conflict security forces during reconstruction efforts. It is a variable that, when accommodating, provides the stability required for reconstruction efforts to take root and focuses initial reconstruction funding on rehabilitation rather than security.

\footnotetext{
${ }^{75}$ Edelstein, 23.

${ }^{76}$ Ibid., 35.
} 
Permissive internal security conditions within the Marshall Plan’s recipient states emerged because of the political cohesion shaped by the external threat of the Soviet Union. Western Europe welcomed reconstruction and rehabilitation programs and the western European regional integration that followed. Accordingly, a safe and secure environment existed prior to the Marshall Plan's implementation and provided a requisite foundation for economic growth and development. ${ }^{77}$ Security laid a foundation for development and focused Marshall Plan funding on the economy. Economic growth was not hampered by internal violence.

\section{Reconstruction Approach}

The reconstruction approach refers to the cooperative or non-cooperative nature of reconstruction programs with the beneficiary state. Cooperative approaches reflect a high degree of coordination and partnership. Non-cooperative approaches are less coordinated with beneficiary states resulting in more burden borne by the benefactor in planning, resources, and execution. Cooperative approaches provide a mechanism that increases the commitment of beneficiary states by providing them increased responsibility and vestment in their recoveries. In post-World War II Western Europe, Marshall Plan participant nations were vested in their recovery, making the Marshall Plan a joint effort rather than a US unilateral effort imposed on Europeans. Europeans themselves played an active role in partially funding the Marshall Plan and implementing the funding within their own economies through their institutions that determined the details of how to do so. In addition to cooperation between the United States and Western Europe through the ECA, recipients also cooperated extensively among themselves through the CEEC and OEEC. This cooperative approach ensured recipient state buy-in and a

\footnotetext{
${ }^{77}$ Edelstein, 35-39.
} 
shared sense of ownership for reconstruction efforts while effectively leveraging the local expertise within western European institutions. ${ }^{78}$

\section{Institutional Strength}

Institutional strength refers to the viability of western political and economic institutions that are widely seen as legitimate, within the beneficiary state. The existence of strong institutions that are experienced in western political-economic principles and have the capacity to perform effectively provide a mechanism to efficiently work through beneficiary states and more effectively leverage local expertise and input into reconstruction programs. Although institutional strength impacts the ability to enact a cooperative reconstruction approach, it also provides insight into the readiness of beneficiary states for western political and economic approaches and provides for useful analysis.

Strong western European political, economic, and social institutions made the implementation of its cooperative approach feasible. After World War II, western Europeans had the political, economic, and social foundations to rehabilitate themselves with help from the United States. The Marshall Plan was not an American solution to Europe’s post-conflict situation. It facilitated a European solution to Europe’s post-conflict recovery and provided the means by which Europeans could implement their solutions in accordance with the guidance and planning of their own institutions. Richard Haass described the important pre-existing foundation for these western European institutions by stating, “[c]ountries like France and Holland endured over four years of German occupation and then suffered physical damage during their liberation. After liberation, however, their citizens resumed the familiar ways of democracy and commerce and could rely on their basic political, economic, and social institutions without fundamental

\footnotetext{
${ }^{78}$ Edelstein, 59.
} 
transformation.”79 The creation of intergovernmental institutions such as the CEEC and OEEC, and internal domestic institutions capable of supporting both democracy and liberal economics that were socially ingrained in post-World War II Western Europe, provided strong western European structures for the Marshall Plan’s implementation.

The pre-existence of these western social, political, and economic institutions facilitated a large top-down fiscal response that is not universally applicable. William Easterly, an international development expert at Columbia University, states that western intervention in a top-down approach aimed at implementing free market policies is likely to fail due to the social intricacies and norms of non-western local markets. In these situations, bottom-up, rather than top-down policy reforms are necessary which reveal that external attempts to adjust the policies of non-western developing states may not yield growth. He argues that western interference in the planning of free markets is unlikely to result in increased growth and development. ${ }^{80}$ Easterly also states, "the West cannot design a comprehensive reform for a poor country that creates benevolent laws and good institutions to make markets work." ${ }^{81}$ These were not concerns in postWorld War II Western Europe. Strong western ideals and institutions were already present, facilitating a large-scale top-down approach through the Marshall Plan that may have otherwise been problematic according to Easterly’s analysis.

West Germany was well poised with the institutional footing required to support effective post-conflict reconstruction. Richard Haass explains that West Germany had "a strong basis for a strong, successful nation-state because of its educated population, pre-war capitalist economy,

\section{${ }^{79}$ Haass.}

${ }^{80}$ William Easterly, “You Can’t Plan a Market” in The White Man's Burden: Why Efforts to Aid the Rest Have Done So Much Ill and So Little Good (New York: The Penguin Press, 2006), 60-61.

${ }^{81}$ Ibid., 100. 
institutions of governance with some degree of popular acceptance and experienced people running them, some history at democratic politics, and a common national identity." ${ }^{82}$ Other scholarly work supports the importance of such previous history by arguing that prior experience with democracy is important in effective democratic consolidation and stability. ${ }^{83}$ In post-World War II Europe, strong, supportive institutions contributed to the Marshall Plan’s success. The requisite pre-existing conditions were in place for this to occur.

\section{Utility of the Marshall Plan as a Strategic Analogy}

The strategic stakes, the external threat perception, the security environment, the reconstruction approach, and institutional strength are contextual variables that facilitated the Marshall Plan's success in post-World War II Europe. Although the Marshall Plan is largely perceived as a success and may serve as a useful historical example of a successful post-war reconstruction, it must be applied with care if it is to be useful as a strategic analogy for future post-conflict recovery. To determine the utility of the analogy to contemporary post-9/11 reconstruction efforts, this research will evaluate reconstruction efforts in Iraq and Afghanistan based upon the identified contextual variables that facilitated the Marshall Plan's success_strategic stakes, external threat perception, security environment, reconstruction approach, and institutional strength—-to determine the usefulness of the analogy's application to the reconstruction challenges in Iraq and Afghanistan.

${ }^{82}$ Haass.

${ }^{83}$ Samuel P. Huntington, The Third Wave of Democracy: Democratization in the Late Twentieth Century (Norman, OK: University of Oklahoma Press, 1991), 271-272. 


\section{Reconstruction in Iraq}

\section{Strategic Stakes}

The war in Iraq that began on March 20, 2003 occurred in a post-Cold War strategic environment with the United States as the lone global superpower. The post-conflict period begins in April 2003 with the fall of Baghdad and proceeds through December 2011 with the withdrawal of US forces from Iraq. This research focuses mainly on the reconstruction decisions in late 2003 that framed the type of reconstruction response that followed. Whereas the Soviet Union posed an existential threat to western capitalist and democratic society during the Cold War, the strategic stakes differed in Iraq. In a speech on the eve of the Iraq War, President Bush painted the Iraqi regime as a threat to peace rather than existence. He stated, “[t]he people of the United States and our friends and allies will not live at the mercy of an outlaw regime that threatens the peace with weapons of mass murder." ${ }^{84}$ In a following speech on September 23, 2003 to the United Nations, President Bush stated that "[a]cross the Middle East, people are safer because an unstable aggressor has been removed from power. Across the world, nations are more secure because an ally of terror has fallen,” and that "a transformed Middle East would benefit the entire world, by undermining the ideologies that export violence to other lands." ${ }^{85}$ Although these pre-conflict comments by President Bush painted the Hussein regime in Iraq as a threat to the United States and its interests, this threat never posed the same existential threat as the Cold War Soviet Union.

The strategic goal in Iraq was vast, establishing a stable democratic government "that will be a launching pad for freedom's success throughout a region that for decades has been a source

${ }^{84}$ George W. Bush, “President George W. Bush’s War Message on March 19, 2003,” Presidential Rhetoric, accessed May 24, 2014, http://www.presidentialrhetoric.com/speeches/ 03.19.03.print.html.

${ }^{85}$ Bush, "Statement by His Excellency Mr. George W. Bush, President of the United States of America Address to the United Nations General Assembly September 23, 2003.” 
of instability and stagnation,” but the strategic stakes were not as high in Iraq as they were in Europe. ${ }^{86}$ Whereas the Marshall Plan was in line with the Truman Doctrine in post-World War II Europe, Iraqi reconstruction was not an integral piece of a foreign policy aimed at an existential threat to western society. Building a stable, democratic Iraq may have served as an example for the expansion of democratic and capitalist ideals in the Middle East, but failure to do so would not pose the same existential threat to western society as the Soviet Union did in post-World War II Europe. Although beneficial and perhaps even a means to reduce future terrorist attacks, building a prosperous Iraq was not necessary to protect the existence of western society itself from a recognized near-peer threat. Lower strategic stakes contributed to less resolve towards a prompt, effective response as seen in the reconstruction approach.

\section{External Threat Perception}

Whereas Western Europe perceived the Soviet Union as a common threat, Iraq did not have such a commonly accepted threat among its population. Competing tribes, ethnicities, and sects detracted from a unified threat picture among Iraqis during reconstruction efforts. The grievances of Sunni, Shiite, and Kurdish Iraqis created an environment where, according to Gideon Rose, “everybody felt threatened by the pervasive lack of personal and communal security." ${ }^{87}$ Without a unifying, commonly identified external threat, some groups saw the United States or competing domestic threats as the greatest challenge to their existence. ${ }^{88}$ Paul Bremer, head of the Coalitional Provisional Authority (CPA) in Iraq, described how this dynamic contrasted to the reconstruction of post-conflict World War II:

${ }^{86}$ US President, The National Security Strategy of The United States (Washington, DC: Government Printing Office, 2006), 13.

${ }^{87}$ Rose, 251.

${ }^{88}$ Edelstein, 159. 
[t]he majority of Iraqis were delighted to see Saddam and his henchmen thrown out, but few were happy to find a foreign, non-Muslim army occupying their country.

And . . .with the Soviet Red Army occupying eastern Germany and Japan's northern offshore islands, the countries defeated in World War II had a strong motive to cooperate with us-nobody wanted the American Army replaced by the Red Army. ${ }^{89}$

Stewart W. Bowen, Jr., the Special Inspector General for Iraq Reconstruction, supported

Bremer's assessment more than eight years after the start of the conflict in his testimony to the

House of Representatives’ Sub-Committee for National Security, Homeland Defense, and

Foreign Operations on June 28, 2012 when he testified:

[i]t is a current and painful reality that Iraqis have not yet fully reconciled their sectarian differences nor established a well-grounded rule-of-law system. These factors are the chief causes of the recent uptick in violence. Until Sunni and Shia achieve improved acceptance of one another in Iraq and until the GOI strengthens its rule-of-law system, the United States will have to invest heavily in protecting its personnel in country. ${ }^{90}$

Without a commonly viewed external threat as a source of cohesion, Iraq's fractured society negatively affected the security environment and the perception of US forces.

\section{Security Environment}

Crime and insecurity hampered the CPA-led reconstruction. ${ }^{91}$ More than eight years after reconstruction efforts in Iraq began, the Special Inspector General for Iraq Reconstruction noted, “all is not yet 'normal' in Iraq, and 'regular order' cannot be immediately reached." ${ }^{22}$ Throughout the post-conflict period, the security environment negatively affected reconstruction and

${ }^{89}$ L. Paul Bremer, III, My Year in Iraq: The Struggle to Build a Future of Hope (New York: Simon and Schuster, 2006), 37, quoted in Edelstein, 162.

${ }^{90}$ US Congress, House, Statement of Stuart W. Bowen, Jr. Inspector General Office of the Special Inspector General for Iraq Reconstruction Before the Subcommittee on National Security, Homeland Defense, and Foreign Operations of the Committee on Oversight and Government Reform, Committee on Oversight and Government Reform, June 28, 2012, accessed June 10, 2014, http://oversight.house.gov/wp-content/uploads/2012/06/6-28-12-NatSec-Bowen.pdf, 4.

${ }^{91}$ Rose, 250.

${ }^{92}$ US Congress, House, Statement of Stuart W. Bowen, Jr., June 28, 2012, 3. 
stabilization efforts. ${ }^{93}$ More specifically, the internal Iraqi security situation detracted from the funding of reconstruction efforts and required a great deal of projected reconstruction funding to be diverted Iraqi Security Forces support. ${ }^{94}$

The internal security environment within Iraq hampered reconstruction project and program implementation and often caused contractors to manage their projects from afar. ${ }^{95}$ In addition, security affected efficiency with ten to twenty percent of reconstruction project costs committed to protection. ${ }^{96}$ Even completed reconstruction projects were not safe with some projects being destroyed after completion. ${ }^{97}$ The security situation during Iraqi reconstruction differed vastly from the permissive environment from which the Marshall Plan benefitted and hampered the effectiveness of reconstruction and rehabilitation in Iraq. Security concerns detracted from reconstruction resources, hampered efficiency, and weakened the foundation for growth.

\section{Reconstruction Approach}

The reconstruction approach differed from the Marshall Plan's cooperative approach in post-World War II Western Europe. The security environment that the US faced in Iraq dictated the resulting reconstruction approach by placing "much of the rebuilding responsibilities primarily onto the shoulders of the US Department of Defense” according to the Special Inspector

${ }^{93}$ US Congress, House, Statement of Stuart W. Bowen, Jr., June 28, 2012, 3.

${ }^{94}$ Special Inspector General for Iraq Reconstruction, Lessons in Program and Project Management, Cyber Cemetery, March 2007, accessed September, 8 2014, http://cybercemetery. unt.edu/archive/sigir/20131001124805/http://www.sigir.mil/files/lessonslearned/Lessons_Learne d_March21.pdf, 10.

${ }^{95}$ Ibid., 79.

${ }^{96}$ Ibid., 105.

${ }^{97}$ Ibid., 78. 
General for Iraq Reconstruction. ${ }^{98}$ A lack of overarching internal Iraqi support for initial reconstruction efforts forced the Americans to use a more direct approach to reconstruction in Iraq rather than the Marshall Plan’s cooperative approach in Western Europe. The more direct approach in Iraq led to deeper divisions within Iraqi society and undermined any efforts at accommodation. ${ }^{99}$ This directive rather than cooperative reconstruction approach in Iraq is seen by the methods used in implementation.

Unable to implement a cooperative approach in Iraq, the United States took a more active role in the approach towards reconstruction than it did in post-World War II Europe. Similar to the Marshall Plan, the United States approached the reconstruction problem in Iraq by providing a large, top-down financial response. Specific to reconstruction in Iraq, Congress initially appropriated \$2.475 billion separately in a large-scale, top-down funding approach to Iraqi reconstruction through the first Iraqi Relief and Reconstruction Fund in April 2003. This funding was aimed at immediate reconstruction needs. In September 2003, Bremer returned to Washington to urge an \$87 billion dollar supplemental budget for operations in Iraq and Afghanistan that passed in November 2003. ${ }^{100}$ In November 2003, Congress appropriated \$18.4 billion in additional funding in a second Iraqi Relief and Reconstruction Fund that aimed at larger scale reconstruction as part of the 2003 supplemental. These funds were managed and implemented through the CPA’s Program Management Office. ${ }^{101}$

${ }^{98}$ US Congress, House, Statement of Stuart W. Bowen, Jr., June 28, 2012, 1.

${ }^{99}$ Edelstein, 163.

100 Jim Garamone, “Bremer Urges Senators to Pass Supplemental Quickly,” Armed Forces Press Service, September 24, 2003, accessed June 2, 2014, http://www.defense.gov/news/ newsarticle.aspx?id=28433.

${ }^{101}$ Special Inspector General for Iraq Reconstruction, Lessons in Program and Project Management, 9-10. 
In addition, as part of a more direct US role in Iraqi reconstruction, the Iraqis themselves did not have the same degree of financial investment in their own recovery. Although Iraqi assets funded a portion of additional reconstruction funding as did Marshall Plan recipient states in Western Europe, these Iraqi funds were not the same joint and vested effort as the fifty-fifty Marshall Plan in Western Europe. Iraqi contributions to reconstruction came through the Development Fund for Iraq that consisted of United Nations Oil for Food Program money and assets frozen or seized from Saddam Hussein and his regime. ${ }^{102}$ Rather than a true joint effort, these assets were not a pure Iraqi investment in Iraq, but an example of the CPA using Iraqi funds available from the international community to augment CPA-led reconstruction.

Further, the approach was not regional as it was in Western Europe and the CPA took a more active role in fund disbursement in Iraq. Initially managed through the CPA, these funds were later passed through the Interim Iraqi Government. However, the CPA continued to manage the budgets passed to Iraqi ministries. Questioning the strength and capacity of Iraqi institutions, the Special Inspector General for Iraqi Reconstruction later stated that "[t]his approach assumed that the IIG ministries had sufficient capacity to carry out these duties” and that “an October 2003 IMF assessment indicated that the implementation of the budget by the Iraqi ministries would require a strengthening of payment and accounting functions, procurement procedures, and internal and external audit functions.” 103

For non-Development Fund for Iraq reconstruction money, the US Agency for International Development and the US Army Corps of Engineers initially took the lead role in US

\footnotetext{
${ }^{102}$ Special Inspector General for Iraq Reconstruction, Lessons in Program and Project Management, 41.

${ }^{103}$ US Congress, House, Statement of Stuart W. Bowen, Jr. Inspector General Office of the Special Inspector General for Iraq Reconstruction Before the United States House Oversight and Government Reform Committee on United States' Involvement in Iraq Reconstruction, GlobalSecurity, February 6, 2007, accessed June 1, 2014, http://www.globalsecurity.org/ military//library/congress/2007_hr/070206-bowen.pdf, 6.
} 
funded reconstruction. ${ }^{104}$ One problem with a US-led reconstruction effort identified by the Special Inspector General for Iraqi Reconstruction was project coordination with the Iraqi government. He stated, "the Iraqi government has woefully insufficient information on what the US government actually constructed and provided.” 105

In an effort to fix this, an agreement with the Iraqi government stated that if the Iraqis were not properly notified about a reconstruction project that they had no obligation to maintain it upon its completion. Among such uncoordinated reconstruction projects was a thirty-five million dollar Commander’s Emergency Relief Program project at the Baghdad International Airport. ${ }^{106}$ This identified problem of implementing large-scale reconstruction projects without Iraqi support and the stated weakness of Iraqi institutions suggests a lack of effective cooperation among US and Iraqi officials during reconstruction and a more direct, American-led approach that contrasts with the joint US-European effort in post-World War II Western Europe.

\section{Institutional Strength}

Iraqi institutions were weaker and did not have the same western foundation as the western European institutions after World War II. Richard Haass compared the existence of strong institutions in Western Europe to the other end of the spectrum where reconstruction must "build from scratch effective and legitimate government structures, a viable economy, and the human capital to make them work. The successes are fewer and the failures are greater because of the magnitude of the task.” ${ }^{107}$ Although Haass did not see Iraq as a worst-case scenario, he did

${ }^{104}$ Special Inspector General for Iraq Reconstruction, Lessons in Program and Project Management, 44.

${ }^{105}$ US Congress, House, Statement of Stuart W. Bowen, Jr., June 28, 2012, 5.

${ }^{106}$ Ibid., 5-6.

${ }^{107}$ Haass. 
question its democratic experience and the effects of both years of economic sanctions and its detachment from the international community. ${ }^{108}$ In 2005, Secretary of State Condoleezza Rice revealed in Congressional testimony that the US plan in Iraq still needed to build strong Iraqi institutions. ${ }^{109}$ These weak, non-western institutions are indicative of the conditions that Easterly sees as unconducive to a large-scale, top-down approach to aid such as the Marshall Plan.

The context of Iraq post-war reconstruction differed significantly from the Marshall Plan's post-World War II context. In Iraq, the strategic stakes were lower, there was no commonly perceived external threat to unify a fragmented population in support of the reconstruction efforts of a non-Muslim foreign power, and the internal security environment was not conducive to an effective rehabilitation. Further, the US approach to recovery in Iraq differed from the Marshall Plan's approach in Europe after World War II. Whereas the post-war reconstruction efforts were truly joint and more cooperative in Western Europe, they were more US centric in Iraq and used American institutions in more of a lead role within Iraq. Institutions in Iraq were not ready to undertake a lead role in their own recovery and the political, social, and economic foundations found in Western Europe were weaker in Iraq. Although the large-scale, top-down fiscal response in Iraq was similar to that of post-World War II Europe, its implementation was not as cooperative, and Iraq’s institutions were weaker. Accordingly, the conditions that enabled the success of the Marshall Plan in Western Europe were not apparent in the context of Iraq's reconstruction, making a Marshall-type response increasingly problematic.

\footnotetext{
${ }^{108}$ Haass.

${ }^{109}$ Rose, 277.
} 


\section{Reconstruction in Afghanistan}

\section{Strategic Stakes}

In continuing to determine the utility of the Marshall Plan as a strategic analogy for contemporary post-9/11 reconstruction efforts, this research will evaluate the post-9/11 reconstruction efforts in Afghanistan with the same contextual variables that contributed to the Marshall Plan's success. In response to the attacks on September 11, 2001, US forces launched attacks the following month that removed the Taliban from power in Afghanistan. In December of 2001, the United Nations established the International Security Assistance Force in Afghanistan to oversee military operations. This research uses December 2001 with the establishment of the International Security Assistance Force as the beginning of reconstruction operations that remain ongoing. Afghanistan reconstruction occurred within the same post-Cold War strategic context as reconstruction in Iraq. Just as in Iraq, this strategic environment lacked an existential threat to American society. In a speech on September 20, 2001, President Bush depicted the threat in Afghanistan as a terrorist threat with the Taliban's oppressiveness seen in Afghanistan as an example of the Islamic extremism espoused by Al Qaida’s worldview. However just as in Iraq, there was not a near-peer existential threat to the western society. This is shown by President Bush's advice for the American people to "live your lives” in the aftermath of 9/11. ${ }^{110}$ Without the existence of a threat strong enough to prevent American’s from shortly going "back to our lives and routines” after 9/11, the stakes of the post-9/11 security environment were low compared to the communist threat depicted by Kennan from the Soviet Union in post-World War II Europe. ${ }^{111}$

${ }^{110}$ George W. Bush, "President George W. Bush's Address to the Nation on September 20, 2001,” Presidential Rhetoric, accessed May 24, 2014, http://www.presidentialrhetoric.com/ speeches/09.20.01.print.html.

${ }^{111}$ Ibid. 
The strategic goal was not as encompassing as that in either Iraq or post-World War II Europe. These situations called for constructing or reconstructing political-economic structure, respectively. The goal in Afghanistan was more limited: to prevent the Taliban from overthrowing the Afghan government and to deny Al Qaida a safe haven. ${ }^{112}$ By 2009, Secretary of Defense Robert Gates saw the more limited Afghan mission as “[d]eny the Taliban momentum and control, facilitate reintegration, build government capacity selectively, grow the Afghan security forces, transfer security responsibilities, and defeat Al Qaeda.”113 To achieve these goals and address the terrorist threat within Afghanistan, US forces removed the Taliban from power, replaced it with a government that posed a lesser threat to US interests, and sought to deny $\mathrm{Al}$ Qaida a base for future operations. ${ }^{114}$ As with Iraq, lower strategic stakes contributed to less resolve towards a prompt, effective response. With the initial emphasis on Iraq from 2003 into 2009, Afghanistan further took a back seat strategically to operations in Iraq.

\section{External Threat Perception}

Unlike post-World War II Western Europe, there was not a commonly identified unifying, external threat among the Afghan populace that allowed them to view an external threat as greater than either the American and coalition forces or domestic rivals. Just as in Iraq but unlike the Marshall Plan’s post-World War II context, Afghani society was internally fractured. According to Edelstein, neither the United States, its North Atlantic Treaty Organization allies, nor the Afghans themselves could collectively see a common external threat. ${ }^{115}$ Without such a

112 US President, The National Security Strategy of The United States (Washington, D.C.: Government Printing Office, 2010), 20.

${ }^{113}$ Robert M. Gates, Duty: Memoirs of a Secretary at War (New York: Alfred A. Knopf, 2014), 375.

\footnotetext{
${ }^{114}$ Edelstein, 156.

115 Ibid., 191.
} 
commonly perceived external threat, US and other foreign forces were not universally

welcomed. ${ }^{116}$ Although social and ideological differences may explain some views towards US forces, a separate external threat may have been a unifying factor that bridged these differences among factions to achieve cohesion for reconstruction. Instead, internal insurgent factions saw the United States as that threat.

\section{Security Environment}

The lack of such a commonly perceived external threat created an internal security environment that differed from that faced by the Marshall Plan in Western Europe, challenging effective reconstruction and development efforts in Afghanistan. Initially in 2001, the United States began working through local tribal or militia leaders to improve security and target $\mathrm{Al}$ Qaida. However, this facilitated unaccountable and counterproductive behaviors from these leaders that, according to John Nagl, "alienated an Afghan population that had been promised a new Marshall Plan by the United States and thereby facilitated the Taliban's reemergence as an insurgency against the new government and international presence.” ${ }^{117}$ An April 2009 terrorism report released by the State Department depicted a security situation incompatible with a large, comprehensive reconstruction approach. It stated that "[t]he Taliban and other insurgent groups and criminal gangs, some of who were linked to AQ [Al Qaida] and terrorist sponsors outside the country, control parts of Afghanistan and Pakistan and threaten the stability of the region.”118

\footnotetext{
${ }^{116}$ Edelstein, 157.
}

117 US Congress, Senate, Statement of John A Nagl, President, Center for a New American Security before the United States Senate Foreign Relations Committee, Center for a New American Security, September 16, 2009, accessed June 21, 2014, http://www.cnas.org/files/ documents/publications/CNASTestimony_Nagl_SFRC_September_16_2009.pdf, 3.

${ }^{118}$ Secretary of State, Office of the Coordinator of Counterterrorism, Country Reports on Terrorism 2009, US Department of State, accessed June 22, 2014, http://www.state.gov/j/ct/rls/ crt/2009/index.htm, 9. 
However, just as in Iraq, the security situation in Afghanistan detracted from reconstruction funding. In April 2010, the Special Inspector General for Afghanistan Reconstruction reported that the majority of reconstruction funding had gone to the establishment and growth of the Afghan National Security Forces. ${ }^{119}$ The inability to access certain areas due to an enemy presence is detrimental to any reconstruction strategy, regardless of its approach and vastly differed from the permissive environment that facilitated the Marshall Plan’s implementation in post-World War II Western Europe.

\section{Reconstruction Approach}

As of April 2014, Congress has appropriated approximately \$103 billion for Afghan reconstruction since $2002 .{ }^{120}$ In spite of differing strategic stakes, the lack of a unifying common external threat, and a security situation that hindered reconstruction, the reconstruction response in Afghanistan was another large-scale fiscal, top-down fiscal response like the Marshall Plan. However, unlike the Marshall Plan, the United States did not implement a cooperative reconstruction approach in Afghanistan.

Internal coordination issues also hampered an effective cooperative approach in Afghanistan. This is evident in a July 2009 Special Inspector General for Afghanistan Reconstruction audit that revealed that there was not a consolidated information management system that tracked and coordinated the reconstruction activities of US agencies in Afghanistan. ${ }^{121}$ The lack of effectively tracking and coordinating reconstruction efforts internally

${ }^{119}$ Secretary of State, Office of the Coordinator of Counterterrorism, 5.

${ }^{120}$ Special Inspector General for Afghanistan Reconstruction. Quarterly Report to the United States Congress, SIGAR, April 30, 2010, accessed June 28, 2014, http://www.sigar.mil/ pdf/quarterlyreports/2010-04-30qr.pdf, 5.

${ }^{121}$ Special Inspector General for Afghanistan Reconstruction, SIGAR Audit-09-3 Management Information Systems, SIGAR, July 30, 2009, accessed June 20, 2014, http://www.sigar.mil/pdf/audits/2009-07-30audit-09-03.pdf, iii. 
across US agencies suggests that any effective external cooperation with Afghan institutions, regardless of their capacity, was ineffective in the least. Further, it depicts problems with a unified US internal cooperative reconstruction approach in Afghanistan, much less with the Afghans themselves. Robert Gates supports this in his memoirs by stating that "[i]n Kabul and all over the country, we and our coalition partners, as well as nongovernmental organizations, far too routinely decided what development projects to undertake without consulting the Afghans, much less working with or through them on what they wanted and needed.” ${ }^{122}$ A July 2012 Special Inspector General for Afghanistan Reconstruction report further emphasizes the effects of such an approach by stating that “[a] significant portion of the US government’s $\$ 400$ million investment in large-scale infrastructure projects in fiscal year 2011 may be wasted, due to weaknesses in planning, coordination, and execution, raising sustainability concerns and risking adverse counter-insurgency effects.” ${ }^{123}$ Neither was there a coordinated, cooperative regional integration nor did the Afghans have the fiscal resources to match a joint approach to reconstruction similar to the Marshall Plan. As a result, they were not equally invested as were post-World War II western European recipient states.

\section{Institutional Strength}

Unlike the strong western European institutions that facilitated the Marshall Plan, Afghanistan lacked the strong western political, economic, and social institutions required to implement a similar reconstruction approach and is an example of the dangers of large-scale, topdown aid approaches stated by Easterly. Ravaged by over thirty years of conflict, Afghanistan did not have the human resources or the institutions required to support a western, democratic-based

${ }^{122}$ Gates, 359.

${ }^{123}$ Special Inspector General for Afghanistan Reconstruction, Quarterly Report to the United States Congress, SIGAR, July 30, 2012, accessed June 28, 2014, http://www.sigar.mil/ pdf/quarterlyreports/2012-07-30qr.pdf, 1. 
cooperative approach.” 124 The institutional capacity in Afghanistan was so weak that the United States abandoned any hopes of creating a strong central government, much less a western democracy. ${ }^{125}$ According to the Special Inspector General for Afghanistan Reconstruction, this weak institutional capacity is directly related to the challenges of reconstruction efforts and longterm sustainability. A July 2012 report to Congress states that "[i]f the Afghan government cannot muster the personnel, skills, funds, and materiel to maintain programs and facilities, then even the best planned and well-executed reconstruction projects are at risk of wasting US tax dollars.” ${ }^{126}$ Therefore, unlike post-World War II Western Europe, Afghanistan did not have the strong western institutional capacity to work, by, with, and through in a cooperative approach to a Marshall-type reconstruction effort.

Just as in Iraq, the contextual variables differed greatly from the Marshall Plan’s postWorld War II strategic context. The strategic stakes were not as high as they were in the bipolar security environment of the Cold War. Unlike the Soviet threat after World War II in Western Europe, there was not a commonly perceived external threat among Afghans to facilitate the actions of US and coalition forces within Afghanistan. Ethnic and tribal factions that did not exist in Western Europe prevented a commonly perceived threat among Afghans. The unstable security situation in Afghanistan hampered reconstruction efforts and diverted funding towards security. Further, the US approach was more direct and less effective. US agencies had difficulties coordinating with themselves, much less effectively doing so with Afghan institutions, regardless of their capacity to assist. In addition, Afghanistan lacked strong western institutions to facilitate

\footnotetext{
2010): 33.

${ }^{125}$ Edelstein, 155-156.

${ }^{126}$ Special Inspector General for Afghanistan Reconstruction, Quarterly Report to the United States Congress, July 30, 2012, 17.
}

${ }^{124}$ John A. Nagl, “A Better War in Afghanistan,” Joint Forces Quarterly 56 (1st Quarter 
a large-scale, top-down reconstruction approach like the Marshall Plan. The weakness of Afghan institutions risks the long-term sustainability of even the best-planned and coordinated reconstruction efforts and vastly differs from the strong western European institutions that facilitated the Marshall Plan and the resulting post-World War II recovery. These differences made a Marshall-type approach much more difficult.

The Marshall Plan Analogy’s Relevance to Recent Reconstruction Efforts

The Marshall Plan’s utility as a strategic analogy for successful reconstruction efforts in Iraq and Afghanistan is poorly applied and out of context. Contrary to those who used the analogy, Iraq and Afghanistan did not need an initial large-scale, top-down fiscal response like the Marshall Plan because the contextual variables that contributed to the Marshall Plan’s success in post-World War II Western Europe were not apparent in these recent reconstruction efforts in Iraq or Afghanistan. This differing context inhibited the successful implementation of a largescale, top-down, fiscal, Marshall-type fiscal response.

Using the Marshall Plan as a strategic analogy for successful post-conflict recovery in Iraq and Afghanistan discounts the differing context. Rebuilding a western society using western norms, ideals, and institutions is much more feasible in Europe than constructing something similar without previous social, economic, and political experiences to support it in either Iraq or Afghanistan. Joseph Nye describes this differing context in post-World War II Western Europe to regions where the Marshall Plan analogy has typically been applied by stating, “[o]ccassionally, people have called for similar Marshall Plans for development in many less-developed regions, but two of the problems with such proposals are the scale of the original plan and the fact that European economies were already developed and needed only to be restored. Moreover, they 
administered much of the aid effectively.” ${ }^{127}$ Therefore, initial conditions and contextual variables matter when using such an analogy.

Implications of the Marshall Plan Analogy’s Usage

The Marshall Plan's use as a strategic analogy for successful reconstruction efforts in Iraq and Afghanistan has troubling implications for operational planners and their development of effective phase IV and V plans when working with unified action partners. Congressional testimony reveals that the poor application of the Marshall Plan analogy to recent reconstruction efforts in Iraq influenced Ambassador Paul Bremer as the administrator of the CPA early in Iraq. In his testimony to the Senate Foreign Relations Committee on September 24, 2003, Bremer suggested an approach to recovery in Iraq that, like the Marshall Plan, was a large-scale, topdown fiscal response. He stated “[o]ur national experience teaches us how to consolidate a military victory . . . [i]n 1948 our greatest generation recognized that military victory was hollow if democracy was not reinforced against tyranny. Democracy could not flourish unless Europe’s devastated economies were rebuilt." ${ }^{128}$ Bremer added "that generation responded with the boldest, most generous and most productive act of statesmanship in the past century—the Marshall Plan” and that “[w]hen Secretary of State George C. Marshall first described the Marshall plan he laid out some truths that resonate today.” ${ }^{129}$ In front of the committee, Bremer said, "[t]he Marshall Plan, enacted with overwhelming bipartisan support, set war-torn Europe on the path to the freedom and prosperity which Europeans enjoy today. After a thousand years as a

${ }^{127}$ Joseph S. Nye, Jr., The Future of Power (New York: Public Affairs, 2011), 78.

${ }^{128}$ US Congress, Senate, Statement of Paul Bremer, Administrator for the Coalition Provisional Authority in Iraq before the Senate Foreign Relations Committee, United States Senate Committee on Foreign Relations, September 22, 2003, accessed June 22, 2014, http://www.foreign.senate.gov/imo/media/doc/BremerTestimony030924.pdf, 2.

${ }^{129}$ US Congress, Senate, Statement of Paul Bremer, 2. 
cockpit of war Europe became a cradle of peace in just two generations.” ${ }^{130}$ Bremer then compared the eighty-seven billion dollar 2003 supplemental budget to the Marshall Plan in Europe after World War II by stating that " [t]he grants to Iraq the President seeks bespeak a grandeur of vision equal to the one which created the free world at the end of World War II.” 131 Therefore, the Marshall Plan analogy directly influenced Bremer as the CPA administrator as he argued for what he saw as a Marshall like fiscal response for phases IV and V in Iraq in a situation that it did not apply. As the president's representative in Iraq, Bremer's view on reconstruction likely permeated through and set parameters within both the CPA that he led and the operational headquarters working with it as a unified action partner in phases IV and V.

Joint doctrine details the influence that unified action or interagency partners, including organizations such as the CPA, have on operational planners. It states that, “[i]n operations involving interagency partners and other stakeholders, where the commander may not control all elements, the commander seeks cooperation and builds consensus to achieve unity of effort. Consensus building is the key element to unity of effort." ${ }^{132}$ An example of the influence of the Marshall Plan analogy and its effects within operational headquarters supporting the CPA is depicted within the military's approach to phases IV and V in Iraq using money as a weapons system. Just as the Marshall Plan analogy proposed a large fiscal response without adequately understanding the contextual differences in Iraq, using money to solve Iraq's phases IV and V problems is evident in an emphasis on money as a weapons system all the way down to the brigade, battalion, and company levels.

\footnotetext{
${ }^{130}$ US Congress, Senate, Statement of Paul Bremer, 2.

${ }^{131}$ Ibid, 3.

132 JP 5-0, II-9.
} 
The forward to a handbook produced by the Center for Army Lessons Learned as a guide for US commanders in Iraq and Afghanistan titled The Commander's Guide to Money as a Weapons System: Tactics Techniques, and Procedures states:

[t]his Center for Army Lessons Learned (CALL) handbook assists company-, battalion-, and brigade-level officers and noncommissioned officers to effectively use money as a weapons system on the counterinsurgency (COIN) battlefield. Coalition money is defeating COIN targets without creating collateral damage, by motivating antigovernment forces to cease lethal and nonlethal operations, by creating and providing jobs along with other forms of financial assistance to the indigenous population, and by restoring or creating vital infrastructure. Money also funds other tools of war. ${ }^{133}$

Among its key lessons are that “[m]oney is a valuable weapons system” and that “[m]oney and contracting in a COIN environment are vital elements of combat power.” ${ }^{134}$ Although this may be true and useful within the appropriate context, using money synonymously with a weapons system suggests that fiscal resources may be expended similarly to ammunition. Although perhaps also true within the right context, the accuracy and effectiveness of such a weapons system is constrained in an environment with non-western institutions within large-scale, topdown approaches.

Although one may argue that the Commander’s Emergency Response Program is intended for small-scale, bottom-up, immediate-impact efforts, the Commander’s Emergency Response Program initiatives that were capped at two million dollars per project without Secretary of Defense approval is hardly a small-scale response. ${ }^{135}$ Comparing fiscal resources to a weapons system depicts how a rather large fiscal response has been suggested at the operational level and based upon the Center for Army Lessons Learned handbook, even affected tactical

${ }^{133}$ Department of the Army, Center for US Army Lessons Learned, The Commander's Guide to Money as a Weapons System: Tactics, Techniques, and Procedures (Fort Leavenworth, KS: Center for Army Lessons Learned, 2009), i.

134 Ibid.

135 Department of the Army, Center for US Army Lessons Learned, The Commander's Guide to Money as a Weapons System: Tactics, Techniques, and Procedures, 18. 
levels down to the company within Iraq and Afghanistan. Although it is not directly explicit that the Marshall Plan analogy that began at the strategic level and appeared at Bremer's operational level in Iraq directly affected the development of The Commander's Guide to Money as a Weapons System: Tactics Techniques, and Procedures and other similarly named publications that influenced operational and tactical phases IV and V actions, the doctrinal emphasis on interagency consensus with a CPA that used the analogy along with the importance of unity of effort in joint operational planning offered a conduit for such effects. Further, the persistence of the Marshall Plan as a strategic analogy for successful post-conflict recovery and the direction of the publication by the Center for Army Lessons Learned down to officers at the company level support how the strategic analogy has been inappropriately applied out of context at the tactical level.

Understanding both strategic analogy and the Marshall Plan analogy’s utility facilitates a deeper understanding of the effects and implications of the Marshall Plan analogy. Just as the use of strategic analogy in Korea, Munich, and Vietnam contributed to seeing situations as something that they turned out not to be, the Marshall Plan analogy likely had similar effects. Using Khong’s analysis of strategic analogy and the evident use of such analogy by senior leaders in Iraq such as Bremer, the Marshall Plan analogy used as a source of strategic guidance caused others to perceive the situation as something that it was not. It influenced both the ability of planners to accurately frame the reconstruction problem, and of others to see the similarities rather than differences in context. It resulted in a prescription for the large, fiscal Marshall-type approach to contemporary reconstruction efforts.

Following Khong's argument, once the Marshall Plan was established as a strategic analogy for success within the CPA, it affected the reconstruction approach and even predicted the effectiveness of a large-scale fiscal response, including the morality of the chosen approach which is evident by Bremer referring to the Marshall Plan in Winston Churchill's terms as "the 
most unsordid act in history.” ${ }^{136}$ Although strategic analogies may be useful as heuristics if contexts are appropriately considered, the use of the Marshall Plan as a strategic analogy for contemporary reconstruction efforts did not adequately account for context, hampering the ability to see through the analogy into the aspects that facilitated the Marshall Plan’s success and the absence of these contextual variables in both Iraq and Afghanistan.

\section{Conclusion}

The Marshall Plan is engrained in both domestic and international political discourse as a strategic analogy for successful post-conflict recovery. Strategic leaders, those that influence them, and even those responsible for recent post-conflict recoveries have used the analogy, calling for a Marshall Plan for Iraq and Afghanistan in the public forum. The Marshall Plan analogy's popularity is not limited to post-war reconstruction and rehabilitation; it has grown out of its original context and is now applied to any large, complex problem, suggesting a comprehensive fiscal response to contemporary socio-political issues including Hurricane Katrina and as a solution to the June 2014 Department of Veterans Affairs crisis.

The Marshall Plan's role in reconstructing Western Europe in the aftermath of World War II within three years and to set it on a path to sustained peace and stability that has now endured for nearly seventy years reveals it as an example of a successful policy response to a post-conflict reconstruction. However, understanding what the Marshall Plan really was, what it did, and its appropriate historical context reveals that its use as a strategic analogy for successful a post-conflict operations is poorly applied to contemporary post-conflict efforts in Iraq and Afghanistan.

As part of the Economic Recovery Act of 1948, the Marshall Plan, as it is popularly referred, provided a large-scale, fiscal response to address a post-conflict recovery that, nearly

${ }^{136}$ US Congress, Senate, Statement of Paul Bremer, 2. 
three years after the war, required an economic solution. The historical context of post-World War II Western Europe set conditions for such a response. The strategic context, external threat perception, security environment, reconstruction approach, and institutional strength provided a favorable environment for the Marshall Plan to succeed. These same contextual variables that contributed to the Marshall Plan's success in post-World War II Western Europe were not evident in recent reconstruction efforts in Iraq or Afghanistan. The use of the Marshall Plan as a strategic analogy for successful reconstruction efforts in Iraq and Afghanistan fails to account for this differing context and results in the Marshall Plan being a strategic analogy that is poorly applied to these contemporary reconstruction efforts.

The poor usage of this strategic analogy affected Paul Bremer as the CPA administrator early in the Iraq War. The effects on the CPA as an interagency and unified action partner, present challenges for the joint operational planner working by, with, and through such partners in phases IV and V. If, as according to joint doctrine, consensus and unity of effort with partners such as the CPA and the organizations within it are essential, then accepting such analogies may impact operational planning and tactical action as seen in money as a weapons system which suggests seemingly large-scale fiscal responses all the way down to the tactical level without an understanding of whether or not such an approach is appropriate within each situation's unique context. The Marshall Plan’s inappropriate use as a strategic analogy and its troubling implications support Gideon Rose’s words of caution that “Americans, and their leaders, need to learn that analogies usually confuse more than they clarify." 137

Although the Marshall Plan is a poorly applied strategic analogy for post-conflict operations in Iraq and Afghanistan with troubling implications for operational planners, the Marshall Plan remains a strong example of a successful post-conflict reconstruction when viewed

${ }^{137}$ Rose, 285. 
within its appropriate historical and strategic contexts. Discounting a large-scale, top-down fiscal response such as the Marshall Plan for all future reconstruction efforts would be shortsighted. Planners must recognize the use of strategic analogy, understand its potential implications when used as a form of strategic guidance, see through analogy to seek the best understanding possible of the context they face, and develop a solution to future post-conflict operations that accounts for such context. As time progresses and long-term Iraqi or Afghan reconstruction successes conducted by forces below the operational level are realized, or not, and additional data is declassified and available for public use, future research should analyze the effectiveness of Department of Defense fiscal-type responses to post-conflict reconstruction at this level via programs such as the Commander’s Emergency Response Program to determine aspects that contributed to its successes or failures to achieve military end states in Iraq and Afghanistan and to evaluate the military's role in development. 


\section{Bibliography}

Alexander, Lamar, Senator. “Alexander: A Marshall Plan is Needed for Iraq.” The Chattanoogan, October 3, 2003. Accessed February 20, 2014. http://www.chattanoogan.com/ 2003/10/3/41700/Alexander-A-Marshall-Plan-Is-Needed.aspx.

Behrman, Greg. The Most Noble Adventure: The Marshall Plan and the Time When America Helped Save Europe. New York: Free Press, 2007.

Beisner, Robert L., Edward M. Coffman, George C. Herring, and Edwin A. Thompson, eds. The Papers of George Catlett Marshall. Vol. 6. Baltimore: John C. Hopkins University Press, 2013.

Bert, Wayne. The Reluctant Superpower: United States Policy in Bosnia, 1991-1995. New York: St. Martin's Press, 1997, 111. Quoted in Jeffrey Record, Making War, Thinking History: Munich, Vietnam, and Presidential Uses of Force from Korea to Kosovo. Annapolis, MD: Naval Institute Press, 2002, 156.

Biden, Joseph R. Jr., Senator. "Opening Statement in the Senate Foreign Relations Committee Hearing on Afghanistan - Time for a New Strategy?” United States Senate Committee of Foreign Relations, March 8, 2007. Accessed May 28, 2014. http://www.foreign. senate.gov/imo/media/doc/BidenStatement070308.pdf.

Bremer, L. Paul III. My Year in Iraq: The Struggle to Build a Future of Hope. New York: Simon and Schuster, 2006, 37. Quoted in David M. Edelstein, Occupational Hazards: Success and Failure in Military Occupation. Ithaca, NY: Cornell University Press, 2008, 162.

Bush, George W. "President George W. Bush’s Address to the Nation on September 20, 2001.” Presidential Rhetoric. Accessed May 24, 2014. http://www.presidentialrhetoric.com/ speeches/09.20.01.print.html.

. "President George W. Bush’s Speech at VMI on April 17, 2002.” Cable News Network. Accessed February 19, 2014. http://cgi.cnn.com/TRANSCRIPTS/0204/17/se.02.html.

. "President George W. Bush’s War Message on March 19, 2003.” Presidential Rhetoric. Accessed May 24, 2014. http://www.presidentialrhetoric.com/speeches/03.19.03. print.html.

. "Statement by His Excellency Mr. George W. Bush, President of the United States of America Address to the United Nations General Assembly September 23, 2003.” United Nations. Accessed February 20, 2014. http://www.un.org/webcast/ga/58/statements/ usaeng030923.htm.

Department of the Army, Center for US Army Lessons Learned. The Commander's Guide to Money as a Weapons System: Tactics, Techniques, and Procedures. Fort Leavenworth, KS: Center for Army Lessons Learned, 2009.

Easterly, William. “You Can’t Plan a Market.” In The White Man's Burden: Why Efforts to Aid the Rest Have Done So Much Ill and So Little Good, 60-111. New York: The Penguin Press, 2006. 
Economic Cooperation Act of 1948. Public Law 472. 80th Cong., 2d sess. April 3, 1948.

Edelstein, David M. Occupational Hazards: Success and Failure in Military Occupation. Ithaca, NY: Cornell University Press, 2008.

Gaddis, John Lewis. The Landscape of History: How Historians Map the Past. New York: Oxford University Press, 2002.

Garamone, Jim. “Bremer Urges Senators to Pass Supplemental Quickly.” Armed Forces Press Service, September 24, 2003. Accessed June 2, 2014. http://www.defense.gov/news/ newsarticle.aspx?id=28433.

Gates, Robert M. Duty: Memoirs of a Secretary at War. New York: Alfred A. Knopf, 2014.

Gore, Al. Earth in the Balance: Ecology and the Human Spirit. Boston: Houghton Miffin, 1992.

Gimbel, John. The Origins of the Marshall Plan. Stanford, CA: Stanford University Press, 1976.

Haass, Richard N. Information Memorandum to the Secretary of State, "Reconstruction in IraqLessons of the Past," September 26, 2002, Declassified and released in full by the US Department of State, September 26, 2012.

Headquarters, Department of the Army. Army Doctrine Reference Publication 3-0, Unified Land Operations. Washington, DC: Government Printing Office, 2012.

Hindustan Times Correspondent. “India Backs Marshall Plan for Afghanistan.” Hindustan Times, December 5, 2011. Accessed February 14, 2014. http://www.hindustantimes.com/worldnews/india-backs-marshall-plan-for-afghanistan/article1-778248.aspx.

Hogan, Michael J. The Marshall Plan: America, Britain, and the Reconstruction of Europe, 19471952. New York: Cambridge University Press, 1987.

Huntington, Samuel. The Third Wave: Democratization in the Late Twentieth Century. Norman, OK: University of Oklahoma Press, 1991.

Joint Chiefs of Staff. Joint Publication 5-0, Joint Operational Planning. Washington, DC: Government Printing Office, 2011.

Khong, Yuen Foong. Analogies at War: Korea Munich, Dien Bien Phu, and the Vietnam Decisions of 1965. Princeton, NJ: Princeton University Press, 1992.

Kissinger, Henry. Diplomacy. New York: Simon and Schuster, 1994.

Knowles, Christopher. “Germany 1945-1949: A Case Study in Post Conflict Reconstruction.” History and Policy, January 2014. Accessed May 6, 2014. http://www.historyandpolicy. org/papers/policy-paper-154.html.

LaFeber, Walter. America, Russia, and the Cold War, 1945-2006. 10th ed. Boston: McGraw Hill, 2008. 
Leffler, Melvin P. The Specter of Communism: The United States and the Origins of the Cold War, 1917- 1953. New York: Hill and Wang, 2004.

Machado, Barry. “A Useable Marshall Plan.” In The Marshall Plan: Lessons Learned for the 21st Century, edited by Eliot Sorel and Pier Carlo Padoan, 51-68. Paris: OECD Publications, 2008.

McNamara, Robert. "Misreading the Enemy.” New York Times, April 21, 1999. Quoted in Jeffrey Record. Making War, Thinking History: Munich, Vietnam, and Presidential Uses of Force from Korea to Kosovo. Annapolis, MD: Naval Institute Press, 2002, 156.

Mee, Charles L. Jr. The Marshall Plan: The Launching of the Pax Americana. New York: Simon and Schuster, 1984.

Merrill, Dennis and Thomas G. Patterson. Major Problems in American Foreign Relations. Vol. 2. 7th ed. Boston: Wadsworth, 2010.

Milward, Alan S. The Reconstruction of Western Europe 1945-51. Los Angeles: University of California Press, 1984.

Morella, Constance A. “Marshall Plan 60th Anniversary Symposium: Introductory Remarks.” In The Marshall Plan: Lessons Learned for the 21st Century, edited by Eliot Sorel and Pier Carlo Padoan, 5-7. Paris: OECD Publications, 2008.

Nagl, John A. “A Better War in Afghanistan,” Joint Forces Quarterly 56 (1st Quarter 2010): 3239.

Neustadt, Richard E. and Ernest R. May. Thinking in Time: The Use of History for Decision Makers. New York: The Free Press, 1986.

Nye, Joseph S., Jr. The Future of Power. New York: Public Affairs, 2011.

OECD. “Organization for European Economic Cooperation,” last modified May 3, 2013. Accessed May 6, 2014. http://www.oecd.org/general/organisationforeuropeaneconomic co-operation.htm.

Orr, Robert C., ed. Winning the Peace: An American Strategy for Post-Conflict Reconstruction.Washington, DC: The Center for Strategic Studies Press, 2004.

Pogue, Forrest C. George C. Marshall: Statesman. New York: Viking Penguin, 1987.

Record, Jeffrey. Making War, Thinking History: Munich, Vietnam, and Presidential Uses of Force from Korea to Kosovo. Annapolis, MD: Naval Institute Press, 2002.

Reid, Harry, Senator, and Representative Nancy Pelosi. "Pelosi and Reid: America Needs Leadership in Recovery, Rebuilding, and Renewal.” Nancy Pelosi, September 15, 2005. Accessed February 21, 2014. http://pelosi.house.gov/news/press-releases/pelosi-and-reid-americaneeds-leadership-in-recovery-rebuilding-and-renewal. 
Rose, Gideon. How Wars End: Why We Always Fight the Last Battle. New York: Simon and Schuster, 2010.

Secretary of State, Office of the Coordinator of Counterterrorism. Country Reports on Terrorism 2009. US Department of State. Accessed June 22, 2014. http://www.state.gov/j/ct/rls/crt/ 2009/index.htm.

Simon, Richard. 2011. “Veterans Group Pushes for a 'Marshall Plan' to Address VA Member Issues,” Los Angeles Times, June 2, 2014. Accessed June 9, 2014, http://www.latimes. com/nation/nationnow/la-na-nn-veterans-va-fixes-20140602-story.html? \{\{\$par $\}$.

Sorel, Eliot and Pier Carlo Padoan, eds. The Marshall Plan: Lessons Learned for the 21st Century. Paris: OECD Publications, 2008.

Special Inspector General for Afghanistan Reconstruction. Quarterly Report to the United States Congress. SIGAR, April 30, 2010. Accessed June 28, 2014. http://www.sigar.mil/pdf/ quarterlyreports/2010-04-30qr.pdf.

. Quarterly Report to the United States Congress. SIGAR, July 30, 2009. Accessed June 28, 2014. http://www.sigar.mil/pdf/quarterlyreports/2009-07-30qr.pdf.

. Quarterly Report to the United States Congress. SIGAR, July 30, 2012. Accessed June 28, 2014. http://www.sigar.mil/pdf/quarterlyreports/2012-07-30qr.pdf.

. SIGAR Audit-09-3 Management Information Systems. SIGAR, July 30, 2009. Accessed June 20, 2014. http://www.sigar.mil/pdf/audits/2009-07-30audit-09-03.pdf.

Special Inspector General for Iraq Reconstruction. Lessons in Program and Project Management. Cyber Cemetery, March 2007. Accessed September, 8 2014, http://cybercemetery.unt. edu/archive/sigir/20131001124805/http://www.sigir.mil/files/lessonslearned/Lessons_Le arned_March21.pdf.

Stoffer, Jeff. “A Marshall Plan for Afghanistan.” The American Legion: The Magazine for a Strong America 176, No. 3 (March 2014): 48-52.

Trachtenberg, Marc. “The Marshall Plan as Tragedy.” Journal of Cold War Studies 7, no. 1 (2005): 135-40.

US Congress. House. Statement of Stuart W. Bowen, Jr. Inspector General Office of the Special Inspector General for Iraq Reconstruction Before the Subcommittee on National Security, Homeland Defense, and Foreign Operations of the Committee on Oversight and Government Reform. Committee on Oversight and Government Reform, June 28, 2012. Accessed June 10, 2014. http://oversight.house.gov/wp-content/uploads/2012/06/6-2812-NatSec-Bowen.pdf. 
. House. Statement of Stuart W. Bowen, Jr. Inspector General Office of the Special Inspector General for Iraq Reconstruction Before the United States House Oversight and Government Reform Committee on United States' Involvement in Iraq Reconstruction. Global Security, February 6, 2007. Accessed June 1, 2014. http://www.globalsecurity.org/military//library/congress/2007_hr/070206-bowen.pdf.

. Senate. Statement of John A Nagl, President, Center for a New American Security before the United States Senate Foreign Relations Committee. Center for a New American Security, September 16, 2009. Accessed June 21, 2014. http://www.cnas.org/files/ documents/publications/CNASTestimony_Nagl_SFRC_September_16_2009.pdf.

. Senate. Statement of Paul Bremer, Administrator for the Coalition Provisional Authority in Iraq before the Senate Foreign Relations Committee. United States Senate Committee on Foreign Relations, September 22, 2003. Accessed June 22, 2014. http://www.foreign. senate.gov/imo/media/doc/BremerTestimony030924.pdf.

US Forces Afghanistan. USFOR-A Pub 1-06, Commander's Emergency Response Program SOP: Money as a Weapons System. United States Military Academy West Point, January 2010. Accessed September 28, 2014. http://www.usma.edu/cnrcd/SiteAssets/SitePages/ Government\%20Publications/CALL\%20MAAWS-A\%20(JAN\%2010).pdf.

US President. The National Security Strategy of the United States. Washington, DC: Government Printing Office, 2006.

. The National Security Strategy of The United States. Washington, DC: Government Printing Office, 2010.

Wexler, Imanuel. The Marshall Plan Revisited: The European Recovery Program in Economic Perspective. Westport, CT: Greenwood Press, 1983.

Wilson, Theodore A. The Marshall Plan: An Atlantic Venture of 1947-1951 and How it Shaped Our World. New York: Foreign Policy Association, 1977.

X. “The Sources of Soviet Conduct.” Foreign Affairs 25, no. 4 (July 1947): 566-582. 